\title{
Poul Behrendt
}

\section{Tekst, historie og samfund}

Om forholdet mellem teori og praksis hos Jørgen Bonde Jensen. hos Villy Sørensen - og $i$ den kritiske videnskab

I.

På mindre end to år har Jørgen Bonde Jensen, som ikke før har udgivet nogen, udgivet ikke mindre end to bøger. Tilsyneladende er de vidt forskellige: den ene handler om 150 års dansk ølproduktion og hedder Carlsberg, den anden handler om Villy Sørensens sk $\varnothing$ nlitterære forfatterskab og hedder Litteræer arkaologi. I virkeligheden handler de om det samme: de drejer sig begge om formynderfortællinger. Begge udkaster de en epokal drøm eller vision, som af Jørgen Bonde Jensen formuleres i generationskonfliktens billede: at fædrenes samfund for tiden er ved at blive afløst af sønnernes, hvis opgave det er at skabe et nyt, antiautoritært fællesskab omkring en broder-lighedsidé, der ophæver de hidtidige modsætninger af klassebestemt, national og racemæssig karakter.

Det er ideen. Men vægten i begge bøger ligger i analyser af, på hvilken måde sønnerne $\mathrm{i}$ deres opgør med fædrene kommer til at gentage den autoritære karakter-struktur, som de netop $\emptyset$ nskede at befri sig fra.

De to bøger former sig altså ikke alene som opgør med et etableret samfund, der står for fald, men også som et selvopg $\varnothing$ r, nemlig med den marxistisk orienterede samfundskritik, som Jørgen Bonde Jensen i sin egenskab af Vindrose-redaktør selv har været en fremstående talsmand for. Carlsberg-bogen munder således ud i en påvisning af, hvordan de epokale autoritets-kon- 
flikter imellem den gamle og den unge brygger Jacobsen gentager sig i forholdet mellem de studenter, der i sin tid udarbejdede bryggeri-rapporten, og de bryggeriarbejdere, som endte med at sætte studenterne på porten for deres faderligt bedrevidende holdning. På lignende måde tager Jørgen Bonde Jensen i Litteraer arkaologi ikke alene afstand fra Jørgen Bonde Jensens egen tidligere analyse af en formynderfortælling, ${ }^{1}$ men i diplomatiske vendinger foretages der også en regulær afbankning af de synspunkter på Villy Sørensens forfatterskab, som Ebbe Sønderriis fremførte $\mathrm{i}$ den ideologikritiske guldmedaljeafhandling om forfatterskabet, som Jørgen Bonde Jensen selv $\mathrm{i}$ sin tid stod fadder til.

Overfor Sønderriis' symptomal-læsning af forfatterskabet og hans påstand om dets grundlæggende greb: »et nutidigt kompleks af oplevelser sammenfattes, projiceres tilbage f $\varnothing \mathrm{r}$ historien - og fremhæves derefter i sin mytiske form som gyldigt mønster for fortolkningen af nutiden «, ${ }^{2}$ sætter Jørgen Bonde Jensen nu påstanden, at Villy Sørensen med Formynderfortallinger har skabt en form for højt bevidst, kunstnerisk stiliseret historieskrivning, som rækker fra oldtids mytologiske dage til et godt stykke ind $\mathrm{i}$ fremtiden. Det bemærkelsesværdige er, at denne tese, som er bogens hovedtese, er fremsat ikke af Jørgen Bonde Jensen, men af Villy Sørensen selv: "Bogen er forøvrigt ikke kun en samling historier, men kapitler af den europæiske psykes historie«, hævder Villy Sørensen i Digtere i Forh $\phi r$, »første halvdel er en regression, en vigen tilbage for udløste problemer, fra nutidens samfund uden centrum gennem det centraliserede middelaldersamfund i opløsning og tilbage til oldtiden og ondets rod, den splittelse som "Duo« handlede om. Her er det tvillingerne JesusJudas der stykkes ud i Paulus-Nero, og dermed er verden gået i stykker. Denne splid følges så videre frem til nutiden og fremtiden, der stadig lider af oldtidsbindinger « $^{3}$

Når denne tese og Jørgen Bonde Jensens forsøg på at hævde dens gyldighed, i det følgende skal udsættes for en mere indgående kritik, så har det flere grunde. Litterar Arkaeologi betegner på mange måder et vendepunkt indenfor marxistisk orienteret 
astetik. Den har som sin ganske klare hensigt at overbinde den modsætning mellem digtning og kritik, som opstod i løbet af de år Jørgen Bonde Jensen redigerede Vindrosen sammen med Ejvind Larsen, og som siden har udviklet sig til en næsten hadlignende aggression fra mange digteres side overfor alt, hvad der har med universitets-litterater at gøre. Det er ikke tilfældigt, at bogen i sin lay-out er en tro kopi af Villy Sørensens Formynderfortallinger, blot med den forskel, at Litterar arkaologi i stedet for formynderen Frederik III på sin forside har et billede af Jørgen Bonde Jensens eget tidligere forbillede: Villy Sørensen, hvis filosofi og æstetik han efter ' 68 i stigende grad bragte sig i modsætning til, indtil han altså nu broderligt søger en genforening med det fhv. fader-imago.

Det gør han blandt andet derved, at hans bog i sit metodiske grundsynspunkt betegner en tilbagevenden til den bærende påstand i Villy Sørensens æstetik: at kunsten repræsenterer en form for erkendelse, der kan hævde sig som selvstændigt gyldig overfor f.eks. en naturvidenskabelig erkendelse. Men synspunktet er i Jørgen Bonde Jensens udgave ikke bare en gentagelse af tressernes kunstsyn. Det har i mellemtiden fået profil og er blevet konkretiseret til pástanden om, at den form for erkendelse, som kan tilkendes ikke alle, men visse former for kunst, er en historisk erkendelse.

I hele sit sigte er bogen på mange måder beslægtet med synspunkter, som for mit eget vedkommende har beskæftiget mig igennem flere år. ${ }^{4}$ Når det derfor om Litterar arkaeologi skal hævdes, at det er en mislykket bog, så er hensigten ikke at lægge afstand til bogens problemstilling, men at gøre opmærksom på spændvidden i dens problemfelt. Har man først lukket op for sammenhængen mellem fiktion og historie, så har man samtidig bundet sig til en række synspunkter og metodiske greb, som forpligter. Disse forpligtelser er ikke hentet ud af den blå luft. $\mathrm{Er}$ Litteraer Arkaologi en mislykket bog, så er målestokken for det vellykkede blandt andet hentet fra J $\phi$ rgen Bonde Jensen selv. Ikke bare fra hans teori, men også fra hvad han har praktiseret, 
nemlig i bogen om Carlsberg. Den betegner det positive standpunkt, hvorfra hans anden bog må negeres.

Når Litterar arkaoologi i det følgende skal gøres til udgangspunkt for en diskussion af en række litteraturvidenskabelige grundbegreber, så kan det altså lade sig gøre, fordi bogen, skønt mislykket, er mislykket på en kvalificeret måde: dens problemer er ikke bare dens egne, men sprækkerne i dens fremstilling danner tilsammen en åbning ind til problemfelter, som ellers kan være vanskeligt tilgangelige.

\section{I. TEKSTEN}

\section{Intern og ekstern kritik}

I forlængelse af det sidste årtis litterære metode-diskussioner kunne man skelne mellem to hovedformer for kritik, som i almindelighed synes at udelukke hinanden. De skal her benævnes intern og ekstern kritik.

Som ekstern kan den kritik defineres, der udfra en forud konciperet teori om samfundets eller psykens indretning læser en forfatters værker som symptomer på konflikter, der ikke har været ham bevidst. I modsætning hertil står den interne kritik, der forholder sig til teksten som et produkt af intentioner, og som anser forfatter-bevidstheden for den $\emptyset$ verst organiserende instans, som det for læseren gælder om at komme til bevidsthed om.

Denne modsatning, der historisk kunne formuleres som en modsætning mellem tidsskrifterne Vindrosen og Kritik, har i stigende grad vist sig uholdbar. Mens den eksterne kritik efterhånden var kommet $i$ den situation at have fordrevet litteraturen fra litteraturstudiet, er det for den interne kritiks vedkommende blevet klart, at korrelationen mellem digter og kritiker hviler på en række samfundsmæssige forudsætninger, som nødvendigg $\varnothing r$ en teoretisk eksplicitering.

Set i lyset af disse bestemmelser er det også tydeligt nok, at Jørgen Bonde Jensen med Littercer arkaologi har ønsket at overbinde denne modsætning. Det er hans bogs centrale bestræbelse. 
Og det er i den bestræbelse at den i eklatant grad må kaldes mislykket. Bogen rummer to klart forskellige fremstillingsformer. På den ene side en række teoretisk ekspliciterende kapitler (kapitlerne 2 og 16-18), på den anden en række konkrete tekstlæsninger, hvor de enkelte fortællinger efter tur gennemgås, én for hvert kapitel (kap. 3-15 samt kap. 19).

Det forholder sig nu sådan, at det tilsyneladende er i de teoretisk anlagte kapitler man møder den interne lasning: ikke alene er bogens tese fremsat af Villy Sørensen, men den grundmures også med citater fra hans фvrige filosofiske forfatterskab, mens det overraskende nok er $\mathrm{i}$ gennemgangen af de enkelte fortællinger at man konfronteres med en læsemåde, som synes at inkludere en total suspension af forfatterbevidstheden. Allerede i den iagttagelse annonceres det dilemma, der er bogens som helhed: at den i sin praksis uddyber den splittelse, som den i teorien $\emptyset n-$ sker at overvinde.

\section{Freud og anagrammerne}

Dette dilemma skal i første omgang studeres i de konkrete tekstlæsninger. Allesammen er de næsten ulæselige, hvis ikke læseren umiddelbart forinden har genlæst den historie, som fortolkes. I stedet for at fors $\varnothing$ ge at sammenfatte de enkelte fortallingers begivenhedsgang og ad den vej skabe et oversigtspunkt for en forståelse, springes der uformidlet ind i en udlægning af den pågældende fortælling, ikke som helhed, men som den stykkevis går for sig. Fremdriften i fortolkningerne udspringer således ikke af en fremadskridende tankegang, men af at fortællingerne selv skrider fremad: "Vi nærmer os Jesu d $\varnothing \mathrm{d} «(24)$, som det hedder, da vi skal over et af de døde punkter i udlægningen af legenden om den onde Judas.

Denne blanding af halvt referat og halvanden forklaring kan lyde temmelig intern, men er i virkeligheden signal for en total nedbrydning af historiernes tilsyneladende sammenhæng til fordel for et bombardement af synspunkter, der kan komme uforudsigeligt mange steder fra: fra græsk mytologi, fra Nicolaus Cusanus, fra Marx, Jung, ordbøger eller bølleoptøjer. Den forvir- 
rende mangfoldighed opløser sig dog for en nærmere betragtning $i$ et nogenlunde fast genkommende associationsfelt af freudiansk oprindelse. Dette felt lader sig nok mest iøjnefaldende studere i Jørgen Bonde Jensens udstrakte brug af anagrammer.

$\mathrm{Nu}$ er det nok de færreste idag som overhovedet aner, hvad et anagram er. Ordet betyder bogstav-ombytning og betegner gerne en selskabelig beskæftigelse blandt forrige århundredes højere borgerskab. Den sidste i Danmark som hengav sig til fornøjelsen, var vistnok Karen Blixen, der lavede anagrammer over de fleste af sine venners og nogle af sine uvenners navne. Over Martin A. Hansens navn opfandt hun anagrammet: han er min satan, mens Jørgen Gustava Brandt blev til: antag at vi er Guds børn. ${ }^{5}$ Som det fremgår, drev hun det så vidt, at anagrammet blev en slags gåde eller nøgle til personens væsen. Mindre kan også gøre det, men så meget står fast: for at anagrammets love skal være overholdt, kræves det, at man benytter samtlige bogstaver i forlægget, hverken flere, eller færre. Ellers er anagrammet ikke en kunst, men en hundekunst.

For Bonde Jensens vedkommende er der ikke det navn i Villy Sørensens fortællinger, som han ikke kan udlede et anagram af. Det er faktisk ingen kunst. For eksempel diskuterer han i forbindelse med Sare Historier, hvorfor den første legendes løver i historien om Tigrene er blevet til tigre, når rovdyrene dog har samme funktion de to steder. Jo, forklarer han, "når løver nu er blevet til tigre skyldes det bl.a. muligheden for at stille dem i et sprogligt belysende forhold til Grethe (222). Hendes navn, må man forstå, er nemlig et anagram for det stribede rovdyr, som den velvillige læser kan se staves: theger. Sådan bliver Bill til regning på engelsk, men læst bagfra til karlig på tysk, Nis bliver til $\sin$ og sin igen til synd på engelsk. Sare historier er et anagram for eros historier (eros den, som eros bør). Og i ordet piccolouniform kan man finde det latinske verbum: colo, så at pic-colo-uniform i virkeligheden betyder: jeg dyrker pikken uniformt. ${ }^{6}$ 


\section{Et eksempel: Theseus, Tesso og tyren}

Disse eksempler er på ingen måde enestående. De hænger sammen med en fortolkningsprocedure, som på afgørende måde styrer læsningen af Villy Sørensens historier. På eksemplarisk vis kan den studeres i Bonde Jensens udlægning af den næstsidste formynderfortælling: I det fremmede. I slutningen af sin gennemgang sammenligner han den med Shakespeare's Skarsommernats$d r ø m$, som han mener kan have været en inspiration for fortællingen og citerer Georg Brandes' karakteristik af Shakespeare's stykke: „Shakespeare har her følt og vist, hvor meget mere vidtstrakt det ubevidste Livs Omraade er end det bevidstes, og har antydet, at Guder som Lidenskaber har deres Rod i det ubevidste«. Det mener Bonde Jensen også gælder for Villy Sørensens fortælling, som »er en anvisning på (og selv et eksempel på) hvordan det ubevidste og det bevidste liv skal (må) integreres $i$ hinanden « (135).

Hvordan denne integration finder sted, skal her studeres lidt nærmere. Når Bonde Jensen af alle tænkelige tekster kommer til at tænke på En Skarsommernatsdrøm i forbindelse med Villy Sørensens fortælling, så kommer det af, at den græske hero Theseus optræder i Shakespeare-stykkets rammefortælling. Det bliver tankeforbindelsen nu ikke mindre overraskende af. For hvordan er Theseus overhovedet kommet ind i Bonde Jensens hoved? For at ingen skal være $i$ tvivl, har han givet sin gennemgang hoved-overskriften: »Theseus, Tesso og tyren«. Men enhver, der har læst Villy Sørensens historie, vil forgæves ransage sin hukommelse for såvel Theseus som tyre.

Når de to alligevel kan gøres til titelfigurer i Bonde Jensens fremstilling, går det sådan til. Hovedpersonen $I$ det fremmede bliver på et tidspunkt installeret på et hotelværelse i en seng, som er for kort. Det mener Bonde Jensen tyder på, at rammerne for hovedpersonens erotiske udfoldelse er for snævre, og tilføjer at sådan en seng kaldes en Prokrustes-seng. Ingen af delene står ganske vist $\mathrm{i}$ teksten, men danner alligevel grundlag for den konklusion, at hovedpersonens opgave følgelig må være: »at finde en større seng og komme Prokrustes til livs« (116). Og hvem 
kom i sin tid Prokrustes til livs? Det gjorde såmænd Theseus, der ganske vist lige så lidt som Prokrustes findes i teksten. Men Prokrustes var ikke den eneste, som Theseus dræbte. Han slog også uhyret Minotaurus ihjel, som selv slog fjorten unge piger og drenge ihjel årligt. Når dertil kommer, at Theseus' stedfader ved en fejltagelse styrtede sig i havet, da han kom hjem fra Kreta og at hans biologiske far, Poseidon, engang forklædte sig som tyr, så er det nærliggende »at opfatte Minotaurus som et billede på formynderen, der $\mathrm{i}$ sin fortrængte dyriskhed vender sig mod ungdommens « (117). Hvis man samtidig beslutter, at I det fremmede i virkeligheden foregår i Spanien, og at Spaniens nationaldyr er en tyr, så kan man udmærket tyde navnet på den tjener, Tesso, der hjælper hovedpersonen hen på et hotelværelse med en større seng, som en spansk form for Theseus og samtidig opfatte Tesso som et anagram over det græske ord, theos, som betyder: gud.

»Og dermed kan vor rejsendes forehavende $\mathrm{i}$ det fremmede defineres, « fastslår Bonde Jensen. »Til forskel fra Theseus gælder det for vores rejsende ikke bare om at dræbe fader-tyren Minotaurus eller diktatoren, som den undertrykkende faderskikkelse på stedet benævnes, men som en forudsætning herfor i f $\emptyset r-$ ste række om at (gen)forene sig med Tesso, den tabte barnlige del af selvet, der bevogtes af både faderen og moderen. Tesso repræsenterer tilknytningen til det ubevidste og er dermed både den levende forbindelse til fødelandet (fostervandet) og til selvforglemmelsen over en anden i seksualakten « (117). Nu gør hovedpersonen ganske vist ikke det mindste tilløb til nogen af delene, men det er netop hans fejl. Derfor kan historiens slutord: ¿ventyr, eventyr «, også helt klart defineres. Førstedelen af ordet eventyr, even, som hævdes beslægtet med effen, kan dialektalt betyde »lige så god som «og optræde $\mathrm{i}$ forbindelsen »blive even med «, der betyder »blive kvit«, »få gjort et regnskab op«. Eventyr kan følgelig læses: »Bliv tyren kvit« (133).

$P \&$ baggrund af Bonde Jensens egne slutord om, at vi her har fået en anvisning på, hvordan det ubevidste og det bevidste liv kan og må integreres $\mathrm{i}$ hinanden, kan og må man således også 
danne sig et første indtryk af det ubevidste. Det ubevidste er overordentlig belæst $\mathrm{g}$ har et vidtgående kendskab til sprog: græsk, latin, italiensk, spansk, engelsk, tysk, fransk og oldislandsk, men ikke sanskrit, kinesisk eller magyarisk. Det kender til specialbetydninger af ord, og ordsammensætninger, som vi andre normalt kun ville kunne finde efter opslag i ordbøger, men er etymologisk set noget af et sjuskehovede. Det ubevidste er desuden helt klart auditivt disponeret, det følger ikke bogstavelige, men lydlige baner, og er også i dette tilfælde tilbøjelig til at se stort på småting: det kan tage navnet Mosetta og trække Tesso fra og nå til det overraskende facit: amo, som betyder jeg elsker Tesso og ikke Mosetta.

\section{Latent og manifest}

Men måske var det rimeligere at stille spørgsmålet: hvilken form for eksistens man kan tilkende en sådan ubevidsthed. Selv taler Bonde Jensen sammenfattende om, hvordan "myten trænger til bunds i sine egne dunkle forestillinger, drømmen er bevidst om sit eget ubevidste, gåden gatter sig selv « (173). Det forekommer altfor beskedent. Den form for tekstlæsning, han praktiserer, forudsætter tværtimod et uoverskrideligt skel mellem bevidst og ubevidst, som alene lader sig begribe i lyset af en freudiansk fortolkningsmåde. Det er Drømmetydning's skel mellem latent og manifest, mellem drømmeindhold og drømmetanker, som gør sig gældende gang på gang, uden at forholdet til Freud på noget tidspunkt ekspliciteres. Han lever med i bogens atmosfære og associationslag så selvfølgeligt, at der slet ikke argumenteres for ham. Således hedder det sammenfattende et sted, at fortællingerne er »fortættede beretninger, hvis manifeste del er lakonisk i forhold til det latente indhold. Hvert manifest element er determineret af flere latente betydninger. Formynderfortællingernes dybdestruktur $g \varnothing r$ fortællingerne til miniromaner og samlingen som helhed til en stor roman« (174). Her kommer psykoanalysen altså til at danne logisk springbrædt for en utroligt vidtgående konklusion, som $\mathrm{i}$ virkeligheden forudsatter en indgående overensstemmelse med Freud. 
Spørgsmålet er, om det lader sig gøre. Skellet mellem latent og manifest drømmeindhold udspringer jo af en konkret erkendelses-situation, som ikke uden videre kan almengøres i en litterær analyse. Skellet svarer nemlig til skellet mellem patienten og lagen, hvis opgave det er at bringe en kritiserende, censurerende instans i patienten til tavshed, for at lade en vegetativ, fri associationsvirksomhed træde i stedet. Hvad der hidtil har ytret sig i forvrænget form, kan nu gennem lægens spørgsmål og tydninger gradvis komme til syne, i en proces, hvorunder det oprindelige indhold efterhånden brydes ned for at remplaceres af en ny tekst, som får status af fhv. ubevidsthed. I denne proces er symbol og symboliseret mildest talt ikke identisk. Tværtimod viser et uendeligt varieret udtryksmateriale sig at være forklædninger for en række fast genkommende grundstørrelser: den infantile seksualitets stadier.

På den baggrund lader det sig også antyde, i hvilken grad Bonde Jensen låner autoritet fra en metode, han $\mathrm{i}$ selve værket er ubemyndiget til at anvende. Hvad der i psykoanalysen er adskilt, er hos ham sammenføjet: den frit associerende virksomhed og den tydende, kritiske instans. Mens den litterære tekst får status af manifest drømmeindhold, veksler Bonde Jensen selv i sin analyse mellem patient- og lægerollen. I det foregående eksempel gik hans associationsvirksomhed fra den korte seng via mellemledene Prokrustes, Theseus, Minotaurus, Tyr, Spanien og frem til diktator, men kun sengen og diktatoren fandtes i Villy Sørensens tekst. Hvad der styrer den mellemliggende associationsgang er således ikke den fortrængte seksualitet hos enten Villy Sørensen, for det er Bonde Jensen, der associerer, eller hos Bonde Jensen, for det manifeste drømmeindhold er Villy Sørensens, men derimod Freuds lære om den infantile seksualitet. De tilsyneladende fuldstændig tilfældige tankeforbindelser viser sig i den påfølgende udlægning allesammen at udspringe af teorien om $\varnothing$ dipalfasens fortrængte fadermord og den polymorft perverse seksualitet. Det tager sig ud, som om vi kontaktede det ubevidste, men det viser sig, at det ubevidste blot er maske for det altfor bevidste: Freud, den store oprører mod over-jeg'ets 
manipulationer, er nu selv blevet installeret som over-jeg og general-manipulator. Skadeligt uskadeliggjort. Det ubevidste er hermed blevet den lettest tilgængelige, mindst kontrollable og mest vilkårlige af alle tekster.

\section{Psykoanalyse og ironi}

Hvad der negligeres her og ofte ellers $i$ anvendelsen af psykoanalysen indenfor litterære sammenhænge, er jo at psykoanalysen kun er sand, for så vidt som den virker. Og dens virkning afhænger alene af, hvorvidt vekselvirkningen mellem læge og patient kan tilvejebringe hidtil skjulte lag af den individuelle erindring; de frie associationer skal ikke føre til en bekræftelse af den freudianske teori, men til berøringen med hidtil fortrængte barndoms-erindringer, og f $\varnothing$ rst via diverse affekt-tilstande, hvor fortiden melder sig i nutiden, er det, at psykoanalysen kan gribe personlighedsmodel-lerende ind. Men en sådan mulighed foreligger jo overhovedet ikke $\mathrm{i}$ forbindelse med en litterær tekst. Den kan ikke gøres til genstand for en psykoanalytisk erkendelsesproces, for den er selv produkt af en sådan. Eller rettere: produkt af en erkendelsesproces, der hævder sig som konkurrent til den freudianske. Mens psykoanalytikeren må nedbryde den manifeste tekst for at tilvejebringe en ny, underliggende tekst, så findes der ingen anden vej til den digteriske teksts latente indhold end dens manifestation, og det er netop et anerkendt kriterium for kvalitet, at latent og manifest, symbol og symboliseret, tydning og erfaring ikke længere lader sig adskille. Heri er der nu ikke noget specielt mystisk, for nøjagtig det samme gælder for en vellykket psykoanalyse: også i det tilfælde er patientens individuelle biografi smeltet uløseligt ind $i$ en freudiansk model for personligheds-udvikling, så at tydning og erfaring ikke længere lader sig adskille, og den infantile seksualitets stadier: oral, anal og фdipal har selv vundet symbolkarakter.

$\mathrm{Nu}$ står det jo enhver frit for at mene, at den freudianske psykoanalyse er en hvilken som helst digter langt overlegen, når det galder afdækningen af de faktorer, som bestemmer det individuelle bevidsthedsliv. Det rejser bare en række erkendelsesteo- 
retiske problemer for en litteraturforsker, som ikke løses via den kortslutning af problemerne, som Jørgen Bonde Jensen foretager, når han identificerer Villy Sørensen med Freud. Derved befinder man sig blot $\mathrm{i}$ den paradoksale situation, at lige meget hvad der falder ham ind under læsningen, kan han rose Villy Sørensen for at have fundet på det.

Det kunne lyde som om der ikke var grænser for, hvad Bonde Jensen kan finde på. Det er sådan set ikke tilfældet. Generelt er han mildest talt ikke så fornemmelsesløs, som de foregående sider har ladet ane. Når det alligevel forekommer at være tilfældet, hænger det sammen med det præg af ulykkelig kærlighed, som hæfter ved Bonde Jensens mangeårige beskæftigelse med Villy Sørensens produktion.

Det er ikke noget tilfælde, når han i en bog, der handler om Villy Sørensens skønlitterære forfatterskab, ikke på noget tidspunkt forholder sig til den ironiske, vittige atmosfære, hvori alle Villy Sørensens historier lever og ånder. Ved at tage samtlige elementer lige fra handlingsgang over personkonstellation til ordspil gravalvorligt, kommer han ikke alene til gang på gang at gå fejl, men også at blive helt ufrivillig komisk.

Eksempelvis i udlægningen af Skrigeren, hvor det hedder: »Hylet er fløjtets komplementære modsætning. Hvor fløjtet udtrykker livsglæde, udtrykker hylet angst for livet, ja dødsangst. Skriget bevæger sig imellem dem og suger dæmonisk næring af begge (74). Det kunne Fifs broder Steen ikke have sagt bedre.

Han dukker op igen og igen, helt ekstremt i kritikken af kritikken af Blot en drengestreg. Det var den daværende radiorådsformand som i 1960 protesterede mod, at historien blev læst op i Danmarks radio: "Det man væmmedes over var sikkert at to drenge saver benet af en anden dreng, så han dør af det. Det man kunne have væmmedes over er grunden til at de gør det« (207), skriver Bonde Jensen, som mener at hele skylden for misèren påhviler naturvidenskaben, som i forældrenes skikkelse fortæller børnene om bakterieangreb: „Hvis de i stedet havde fået at vide at sygdomskampen $i$ onkelen var endt med et beklageligt nederlag for det levende, dyriske ben, så ville de måske 
have fået sympati for det dyriske ben og beskyttet det levende og kæmpet for det til det sidste« (208). Men hvad skulle så alle de lærervikarer have gjort, som i 60 'ernes folkeskole brugte historien til at skræmme uregerlige klasser langt ind $i$ et fascineret musehul? Radiorådsformanden synes at reagere mere træfsikkert på historiens effekt end Bonde Jensen, selvom resultatet af de tos kritik kommer ud på ét: historien får slet ikke lov til at eksistere. Den samme mangel på sans for Villy Sørensens sære ironi får også Jørgen Bonde Jensen til henne i slutningen af sin bog at forkaste Villy Sørensens frodige første fortællinger til fordel for de tørre og udspekulerede Formynderfortallinger, fordi han her kan se en mening med de ordspil, som forekommer ham helt meningsløse i Sare historier.

\section{Alternativet}

Ser man nu disse problemer i lyset af Bonde Jensens Carlsbergbog, som har undertitlen Et københavnsk drømmebillede, så er det karakteristisk at de i den er løst, fordi de er stillet på en anden måde. Også her drejer det sig om et stykke drømmeanalyse; blot analyseres drømmene ikke udfra en freudiansk associationsmetodes absolutering af modsætningen mellem latent og manifest, men i forlængelse af Walter Benjamins tese om tvetydigheden som dialektikkens stilstand: »Enhver epoke indeholder jo ikke blot drømmen om den næste, men den søger i drømmen frem mod sin opvågnen. Den bærer sin egen afslutning i sig og anvender - som allerede Hegel erkendte - list for at nå frem til den. Med vare $\emptyset$ konomiens krise begynder vi at erkende borgerskabets monumenter som ruiner allerede $f \varnothing r$ de er faldet sammen « (3). Udfra den forudsætning analyseres de arkitektoniske vidnesbyrd, som Carlsbergs to grundlæggere, den gamle og den unge brygger Jacobsen, har efterladt sig. Den æstetiske analyse af disse forstenede drømme leder ikke alene ud i den makrostrukturelle overgang fra borgerlig-kapitalistisk smådrift til kapital-teknokratisk stordrift, men ser den samtidig individualiseret i generationskonflikterne mellem de to bryggere.

Den humoristisk indforståede distance, som er forbundet med 
et sådan synspunkt, kan på én gang lade fænomenerne stå ved deres værd og opløse dem i deres indre modsætninger, også i en psykologisk analyse. Et enkelt eksempel må gøre det. Det er et brev, som den gamle Jacobsen sender sin søn Carl på hans 13års fødselsdag. I forvejen har Bonde Jensen fortalt om drengens opvækst, om den arv, der har været lagt på hans skuldre, lige fra faderen på hans fem års fødselsdag døbte sit nye bryggeri Carls-berg, og om den nervøse stammen, som til faderens stigende irritation og på trods af alle formaninger og kurrejser fulgte sønnen livet igennem: »Min kære Carl! Dersom Du havde været en rigtig flink og flittig Dreng i det sidste Aar, skulle hosliggende Uhr have været Din Ejendom idag. Nu kan jeg ikke give Dig det, fordi Du ikke har fortjent det. Jeg haaber imidlertid, at $\mathrm{Du}$ vil bestræbe Dig for at fortjene det. Derfor vil jeg laane Dig det til at se paa og rette Dig efter paa Dit Værelse, men Du maa ikke bære det før Du atter er rykket op til den Plads i Klassen, som Du tidligere havde. Din kærlige Fader Jacobsen « (42). Som Bonde Jensen lakonisk fastslår: „Sådan tugter man ikke den man elsker, sådan straffer man kun sig selv eller den hvori man ser sig selv« (43).

Med den problemstilling er der samtidig åbnet for den anden metodiske hovedtilgang i Litteraer Arkoologi: den interne læsning af formynderiets historie, som fortætter sig i de teoretisk anlagte kapitler. Til grund for denne læsning ligger en række samfundsmæssige implikationer omkring forholdet mellem subjektivt og objektivt, mellem individ og samfund, som i første omgang skal tages op til diskussion. Herved bliver der samtidig lejlighed til at profilere de skjulte modsætninger mellem Litteraer arkaologi og Carlsberg-bogen.

\section{SAMFUNDET}

\section{Bevidsthed og komposition}

Mens det i Bonde Jensens konkrete tekstlæsninger aldrig er til at vide, på hvilket tidspunkt historiernes tingsverden kan opløse sig i seksual- og andre symboler, så udgår han i sin kompositionsanalyse af Formynderfortallinger fra fortællingernes umiddelbare 
overflade, deres emne og dets kronologiske tilhørsforhold til et tidspunkt indenfor de sidste 2000 års historie. Her opereres der ikke med en forfatter(u)bevidsthed, som må fremanalyseres via et konstruktionsnet af associationer, men en indlysende klar bevidsthed, som giver sig dybtgående til kende $i$ et ydre arrangement.

Gangen i bogen sammenlignes af Bonde Jensen med et herresving, der først slår et slag ind i fremtiden med det skræmmebillede, som udmales i En Glashistorie, hvorefter det via middelalderfortællingen om Frederik III bevæger sig tilbage til tidens begyndelse med legenderne om Judas og om Paulus, for derpå at svinge ind $\mathrm{i}$ en fornyet beskæftigelse med nutiden $\mathrm{i}$ Chefen, Skrigeren etc. og endelig demonstrere problemernes mulige forløsning i den afsluttende Fremtidshistorie.

Denne kompositoriske spiral, fra fremtid via nutid ind $i$ fortid frem til nutid og ind $i$ en fornyet fremtid, har Bonde Jensen valgt $i$ sin egen fremstilling at rette ud $i$ et kronologisk ligel $\varnothing b$ fra år et og fremefter. Det hænger sammen med bogens påstand om, at legenden Om den onde Judas svarer til En Fremtidshistorie som ideal til realitet. I legenden fremtræder den polaritet $\mathbf{i}$ rendyrket skikkelse, som resten af bogen bevæger sig indenfor, indtil den opløses og forløses i den afsluttende fremtids-fortælling.

I Jesus-skikkelsen, hævdes det, er det menneskelige fuldkomment og forbilledligt realiseret: "Han er ikke den der kun vil kendes ved det fastslået gode; han fordømmer ingen og han er ikke ensidig åndelig anlagt. Han sætter ingen grænser for kærlighedens udfoldelse, accepterer mors og søns kærlighed, ludere og gale menneskers hengivenhed og han har forstand på penge og véd at fornødenhederne er flere. Han er et stort stykke af en materialist. Samtidig med at han forkynder at ét er fornødent « (26). Som en modpol til denne $\emptyset$ nskedrøm, om hvem man hverken kan vide, hvorfra han er kommet eller hvor han går hen, står Judas-skikkelsen, hvis ødipalhistorie kun synes altfor velkendt og som er splittet $i$ alle de forhold, hvor Jesus er samlet. Mens 
Jesus ikke skelner mellem åndeligt og materielt, forstår Judas det materielle altfor åndeligt og det åndelige altfor materielt.

Denne opfattelse af legenden, hvis nyhed der gøres et stort nummer ud af (her er det ikke kun Sønderriis, men også mig, der bliver dunket i hovedet), medfører ganske vist nogle komplikationer, fordi Bonde Jensen ikke på noget tidspunkt g $\phi \mathrm{r}$ det klart, hvor grænsen går mellem Villy Sørensens, middelalderlegendens og evangeliernes Jesus-skikkelse. Han associerer frit imellem de tre tekster, så når det om Judas hedder, at »Jesu død bogstavelig talt for hans skyld fatter han ikke « (26), så må det indrømmes, at det gør jeg heller ikke. Med mindre man altså skal tage det Thomas Aquinas-motto alvorligt, som Villy Sørensen nok så ironisk har anbragt over legenden: „O lykkelige skyld, som har gjort sig fortjent til så stor en genløser " "?

I hvert fald spiller den stedfortrædende frelse også en fremtrædende rolle i Bonde Jensens opfattelse af En fremtidshistorie. Meningen med fortællingen synes at være den: i hovedpersonen Filius' skæbne gentages de ødipale hovedpunkter, børneforbytningen, samlejet med moderen og drabet på faderen, som også udgjorde hovedpunkterne i Judas' historie. Forskellen er blot, at mens de i Judas' tilfælde førte til splittelse, død og ulykke, så danner de i Filius' tilfælde frelses-forudsætningerne for grundlæggelsen af et nyt samfund: »Hele historien kan læses som en beretning om Guds søn, der lader sig føde som menneske og dermed giver sig ind under nødvendighedens lov, for at bryde den, og derfor udelukkes fra samfundet og siden må leve som outsider hos den gamle hedenske frihedskæmper (ikke f.eks. hos den gamle kristne præst), indtil han vender tilbage med sin plejefars hjælp. Forbogstaverne i Filip Rose og Filius Rose er FR, der indleder ordet frelser « (152).

\section{Objektivt og materielt}

Sammenholder man nu disse psykologiske polaritets-begreber med Bonde Jensens freudiansk inspirerede udlægningsmåde, så er det ikke urimeligt at stille det spørgsmål, som Bonde Jensen 
selv stiller henne over midten af sin bog: "Med Lukàcs ved hånden kunne man bebrejde Formynderfortallinger at de forvandler de historiske forhold til kulisser for en indre, moderne problematik, splittelsesproblematikken. Ja, man kunne sige at de overhovedet forvandler den objektive tingsverden til et forråd af rekvisitter for den psykologiske kunstud $\varnothing$ velse (...) Har 'virkeligheden' selvstændig eksistens i (for) disse fortællinger? Savner disse »kapitler af den europæiske psykes historie « ikke en forankring i den objektive virkelighed? Forvandles psyken ikke til en monade med sin egen af omgivelserne uafhængige udvikling? « (182).

Sådan som spørgsmålene stilles indenfor rammerne af Litterar arkaologi, mener jeg helt afgjort de måtte besvares bekræftende. Det drejer det her ikke om, hvem der har det rigtige synspunkt på Formynderfortallinger, men om på hvilken måde Bonde Jensen argumenterer for en tilbagevisning af spørgsmålene. Det gør han først og fremmest ad to veje: dels ved at hævde fortællingernes materielle virkelighedsforhold, dels ved at hævde et andet objektivitets-begreb end det, spørgsmålene forudsætter.

Hvad fortællingernes materialistiske karakter angår, så mener Bonde Jensen, at den er »sikret ved deres karakter af citatsamling, ved deres dokumentariske karakter, ved deres stadige forholden sig til identificerbare virkeligheder« (187). Spørgsmålet er, hvad man kan forbinde med ordet materiel i en sådan sammenhæng. Det indgår også som klangbund under bogens titel, Litteraer arkacologi, „der på én gang er en metafor for bogens (Formynderfortællingernes) tema og dens teknik - og for behandlingen af bogen - også i den prægnante forstand at arkæologi er den videnskab der beskæftiger sig med fortiden som den manifesterer sig i de materielle levn « (191). Nu vil enhver, der kender lidt til arkæologiens historie, vide at den fremfor noget er de grasserende fantasteriers historie. Langt fra at de materielle levn skulle sikre et historisk virkelighedsforhold, synes de, såsnart arkæologen er færdig med at veje og måle, at forvandles til gasarter i helt løsslupne former for ballonfærd. Er der materialhistorisk set noget som helst beroligende ved, at en forfatter $i$ 
udstrakt grad bygger sit værk op på åbenlyse eller skjulte citater fra et 2000-årigt tekstudvalg? Er det materielle ved et citat andet end de bogstaver, som går igen, mens meningen ændres med konteksten?

Spørgsmålet om konteksten kan man bedst nærme sig via Bonde Jensens anvendelse af ordet objektiv. Ligesom begrebet materiel låner det sin underforståede høje værdi fra marxismens grundbegreber, men undergår samtidig i Bonde Jensens anvendelse en betydningsglidning, som ikke efterlader meget andet af den oprindelige mening end reklameværdien. Snart identificeres det objektive med de $\varnothing$ konomiske forhold (183), snart med et naturvidenskabeligt virkelighedsbegreb (172), og snart med det forhold, som også ordet materiel dækker: at Formynderfortallinger benytter sig af skjulte citater $(19,187)$. Mens ordet $\mathrm{i}$ sidste tilfælde er positivt ladet, er det i næstsidste negativt og i første snart positivt, snart negativt ladet, altefter om det er vendt polemisk mod Lukàcs eller ej. Under alle omstændigheder står det $\mathbf{i}$ modsætning til begrebet subjektiv, som altså snart bliver en betegnelse for alle fejlkilders hjemsted, snart for den frie, etiske og verdens-forandrende handlen. Via betydningsglidninger skabes der et helt overfladisk legitimations-apparat for Villy Sørensens fortællinger, som ingen i virkeligheden kan være tjent med.

\section{Subjekt og objekt}

Hvis ikke en litterær kritik skal ende $i$ en form for skjult moraliseren, er det nødvendigt at klargøre sig den betydningsglidning, som begrebsparret subjektiv/objektiv undergår, når det flyttes fra en naturvidenskabelig til en humanvidenskabelig sammenhæng. Indenfor en naturvidenskabelig kontekst er det subjektive underordnet det objektive: en fællesbetegnelse eller en restkategori for de perceptionsformer (f.eks. smag, lugt, farve) og tænkemåder (f.eks. hensigtsforklaringer), som er ugyldige indenfor en objektiv videnskabssammenhæng. Omvendt indenfor humanvidenskaberne, hvor det objektive, hvis det overhovedet skal forbindes med en mening, må opfattes som et særligt, selvstændiggjort aspekt af det subjektive. Mens det subjektive indenfor na- 
turvidenskaberne fører en bestandig vigende eksistens, så gælder det indenfor humanvidenskaberne om stadig at reducere og opløse det objektive, som her er en betegnelse for det ubevidste eller førbevidste. Det, som skønt menneskeskabt, dog har fået overmenneskelig skikkelse.

De objektive historiske forhold er en betegnelse for de sociale omstændigheder, som subjektet ikke umiddelbart har bevidsthed om, for så vidt som de opleves udfra den individuelt begrænsede placering i samfundsklasse, -rum og -tid. Objektive er de blandt andet fordi de ikke kan erkendes efter deres formålssammenhæng, eller fordi individet ikke er i stand til at identificere sig med deres formål, men alene oplever dem som hæmmende eller fremmende i forhold til egne individuelle $\emptyset$ nsker og behov. Men objektive er de først og fremmest derved, at en formåls-analyse, som udspringer fra den individuelt begrænsede motiv-verden, er ude af stand til at orientere sig indenfor dette sociale rum. Det er de åndfulde kortslutningers rum, hvor f.eks. Vietnam-krigen forklares som udtryk for splittelsen i det europæiske menneske, der må anbringe det onde uden for sig.

At forstå de objektive sociale forhold vil ikke sige at tilskrive dem hensigter, som intet menneske $i$ verden har, men at erkende dem ad historisk vej, dvs. at opløse det tilsyneladende autonomt eksisterende i de arkæologiske lag af formålssammenhænge, som har dannet det. Udfra det synspunkt vil det objektive altså vise sig som produktet af hinanden krydsende eller overlejrende hensigter eller altså: som den del af fortiden, som fortsat eksisterer, og $\mathrm{i}$ den forstand som et aspekt af det subjektive, menneskeskabte. Et nærliggende eksempel på en objektivt set nogenlunde formålsløs institution er landets største arbejdsplads: universitetet - for en synkron analyse et fuldstændig uigennemsigtigt og menneskeopløsende amfibium, der højst lader sig begribe via en historisk erkendelse, som måtte tage sin begyndelse tilbage ved middelalderens slutning for derfra at slå ned på de afgørende skred: f.eks. ved reformationen, ved forrige århundredes begyndelse og slutning, og indenfor det sidste årti.

Helt kort og skematisk kan det objektive $i$ en historisk-sam- 
fundsmæssig sammenhæng siges at bestå af tre grundelementer: 1. produktionsforhold og -redskaber, 2. det sociale og institutionelle hierarki, 3. bevidsthedsformerne. Deres indbyrdes forhold kan anskueligg øres i følgende figur:

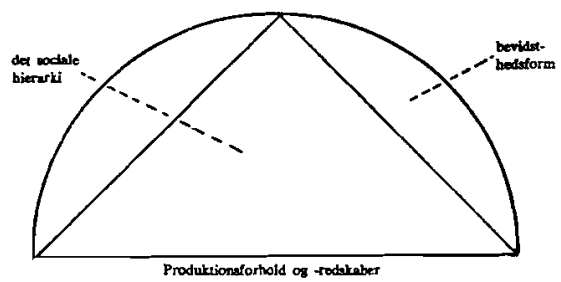

Man kan sige, at de tre elementer fra basis og opefter samtidig betegner faldende grader af materialitet, med bevidsthedsformen som den usynligste, mindst bevidste komponent (bevidsthedsform her defineret som: det $i$ ens væsen, som er ubetvivlet, det i ens måde at tænke, sanse og opleve på, som er så uvilkårligt, at man - med urette - regner det for almenmenneskeligt). ${ }^{8}$ Desuden at ændringer i ét plan næsten altid er sammenkædet med ændringer i de to andre. Og endelig at den indbyrdes forbindelse imellem de tre udgøres af $\phi$ konomiske processer, som det ikke giver mening at studere isoleret, men nok som sammenfatningen af de objektive historiske forhold.

$\mathrm{Nu}$ ville det rigtignok være en fejltagelse, hvis man indvendte, at det ikke ændrede det mindste i verdensmarkedets prisdannelse, valutakurserne eller udsvingene på oliepriserne i Rotterdam, såfremt det rent faktisk lykkedes at trænge frem til en erkendelse af de størrelser, som udvirker de skiftende stigninger og fald. Indvendingen, som bygger på den underforståede forudsætning, at det objektive er identisk med de sociale forhold, som ikke lader sig ændre (med mindre samfundet som helhed ændres), hænger sammen med den fejltagelse, at det subjektive skulle være en betegnelse for det vilkårlige og foranderlige. I den opfattelse mødes selvundervurderingen af det subjektive (som alle fejlkilders udspring) med selvovervurderingen (den frie, emanciperede handlings sted). 
Som næunt implicerer Litterar arkaoologi på afgørende punkter en forblanding af disse to synspunkter, hvad der skal demonstreres i forbindelse med behandlingen af Villy Sørensens En fremtidshistorie i det følgende hovedafsnit. Her skal i første omgang fremsættes en alternativ opfattelse af forholdet mellem subjekt og objekt, sådan som den efter min mening kan findes repræsenteret i Jørgen Bonde Jensens bog om Carlsberg. Der skal fra bogen fremdrages tre eksempler på, hvordan objektive samfundsmæssige modsætninger uløseligt indgår $\mathrm{i}$ forhold, man almindeligvis plejer at kalde private eller subjektive.

\section{Et eksempel: bryggeren og hans sфn}

Som før nævnt bygger Carlsberg-bogen ligesom Formynderfortallinger på en generationskonflikt. Det betyder ikke, at sociale og $\emptyset$ konomiske sammenhænge privatiseres ned til overkommelige intimsfæreproblemer, men tværtimod at fader-s $\varnothing$ n relationen gennemlyses og stiliseres, så at generationskonflikten bliver gennemgangsled for en beskrivelse af et stykke kapitalistisk udviklingshistorie. Det abstrakte, objektive i storkapitalens tilblivelse bliver ikke forflygtiget, men konkretiseret.

For nu selv at blive konkret: konflikterne mellem den gamle og den unge brygger Jacobsen udledes af tre grundlæggende forhold. Hver især kan de relateres til en af de tre grundst $\varnothing$ rrelser, som indgik i den tidligere opstillede skema-model. Det første forhold har at gøre med bevidsthedsformerne, det andet med de sociale hierarkier, det tredie med produktionsforhold og -redskaber. Alle tre stiliseres omkring kapital- og varerelationer, og ingen af dem lader sig behandle isoleret fra de to andre.

Det første konfliktforhold har at gøre med en latent selvmodsigelse i den gamle Jacobsen: i skæbne og livsstil personificerer han den typiske borger, der i kraft af flid og talent har arbejdet sig op til en selvstændig bedrift, en privat kapital, og dog opfatter han sin søn ikke som individ, men som repræsentant for slægten. På den ene side appellerer han til sønnens evner, flid og personlige ansvar, på den anden side ser han intet andet formål med opdragelsen end faderens forherligelse: „Du staar nu fuldt ud- 
rustet til Løsningen af Din Opgave, som næppe nogen yngre, end sige aldre, Brygger i Europa og med en Interesse for Dit Kald, der berettiger til de skønneste Forhaabninger. Og hvilket Haab kan for mig være sk $\varnothing n$ nere end det, at se det Maal, der fra min Ungdom har foresvævet mig, realiseret af Dig « (44), som faderen skriver til sønnen på hans 28 -års fødselsdag.

Den indbyggede modsætning mellem feudalt og borgerligt, som kan spores overalt $\mathrm{i}$ faderens udfoldelser, helt ud $\mathrm{i}$ hans hellensk inspirerede arkitektur, resulterer hos sønnen i en lige så selvmodsigende blanding af total underkastelse og dybt fjendskab. I alt hvad han gør livet igennem, ønsker sønnen at efterligne faderen, men altså at efterligne ham ved at udkonkurrere og overtrumfe ham.

Dette konkurrence-forhold, som nedbryder slægtsforholdet, hænger imidlertid sammen med den anden grundlæggende faktor: kapitalakkumulationen, som frister til ekspansion udover det personligt overskuelige. Livet igennem har faderen set sin virksomhed i lyset af den romantiske enhedsfilosofis organiske verdenshele: en brygmester må i sin egen person overbinde den arbejdsdeling, som bliver hans undergivnes skæbne, og ikke alene have evner og indsigt i samtlige led af brygge-processen, men også indenfor videnskab, kunst og politik. Derfor er ikke alene sønnens totale uddannelsesprogram anlagt med henblik på at fremme den personlige universalitet, men faderen har også fastsat en maksimumsgrænse for en ansvarlig, personlig og kvalitetsbetonet $\emptyset$ lproduktion. De første tilløb til åbent fjendskab imellem de to bryder da også frem i det øjeblik sønnen overskrider denne faderlige grænse på 65.000 tønder. Som Bonde Jensen fastslår i forbindelse med de følgende generationskonflikter: »Det var to tidsaldre der stødte sammen « (46), og det paradoksale er, at det i sammenstødet er den gamle tid som må give tabt for at vinde over den nye: da det ikke lykkes faderen at tvinge sønnen ned under grænsen for mådehold, kaster han sig selv ud i en uhæmmet konkurrence for ad den vej at holde sønnen i ave.

Forudsætningen for at denne ekspansion kan komme i stand, må imidlertid ikke alene søges i den tilsyneladende selvmodsigelse 
hos kapitalen: at den bliver grundlagt i kraft af individuelle evner, flid og mådehold, for derefter at opløse individet i tilfældighed og anonymitet. Den må også søges i de teknisk-videnskabelige nyvindinger som muligg $\phi \mathrm{r}$ en $\phi$ get produktion. Til at udtrykke dette problemkompleks samler Bonde Jensen sin fremstilling omkring garingsprocesserne. Det drejer sig om det forhold, at ølbrygningen af uforklarlige grunde kunne slå fejl, også efter at man havde overtaget Pasteurs opdagelser vedrørende rensning af gæret. Mens Pasteur antog, at forureningen i bryggeprocessen måtte stamme fra udefra kommende forhold, opdagede en af Jacobsens egne forskere, at forureningen stammede fra gæret selv. Den opdagelse stred mod hele den organiske naturfilosofi, hvorpå brygmesterens livssyn hvilede og først da han opgav $\sin$ indædte modstand mod opdagelsen, kunne ølproduktionen skride ind $\mathrm{i}$ sin egentlig ekspansive fase: $\gg$ Det at de vilde, naturlige gærarter kunne fremkalde »sygdomme« i øllet kunne J. C. Jacobsen ikke forlige sig med og han betvivlede rigtigheden af det. Naturen var god. Det var rimeligt, som Pasteur anbefalede, at beskytte den mod angreb udefra, men at den i sig selv skulle rumme modsatninger der under givne omstændigheder ( $\varnothing$ lgæringen) var destruktive måtte han afvise« (38).

$\mathrm{Nu}$ er det vel nok ikke nogen meget mindre betænkelig sag, at Bonde Jensen i stedet for naturens harmoni i gæringsprocesserne synes at finde et bevis på klassekampens sandhed. Men det afgørende i denne forbindelse er selve det forhold, at de konkrete, individuelle og private konflikter hvergang viser sig at pege ud over sig selv og at være funktioner af forskellige former for objektive samfundsmæssige modsætninger: modsætningen mellem feudalt og borgerligt, modsætningen mellem borgerligt og kapitalistisk, og modsætningen mellem organismetænkning og positiv videnskab. Det spændende ved Bonde Jensens fremstilling er, at han ikke forlods parodierer faderens kærlighed til sønnen, men demonstrerer hvordan denne kærlighed i sig selv korrumperes af de objektive modsigelser, som faren i sin opdragelse og i sine konflikter er redskab for, uden at vide af det - og fordi han ikke ved af det. Objektive er de, fordi de er ubevidste, og ikke fordi 
de skulle være eksterne $\mathrm{i}$ forhold til hans egne motiver, for det er de ikke.

\section{Tolkning og erfaring}

På denne baggrund skulle det også være muligt at tegne konturerne af en kritisk videnskab, som fundamentalt er af socialhistorisk karakter. Det forholder sig jo sådan, at i samme фjeblik skellet mellem subjektivt og objektivt er sat, er det også allerede i færd med at blive nedbrudt, nemlig i det subjekt, som fors $\emptyset$ ger at erkende de objektive sociale forhold. Det afgørende, ikke bare teoretiske, men også praktiske problem er, på hvilken måde denne erkendelse finder sted.

I en instruktiv artikel om dette problemfelt: „Historiens uensartethed. Resumé om historie og litteraturlæsning “" har Peter Madsen foreslået følgende arbejdsdeling: mens socialhistorikeren og den $\emptyset$ konomiske historiker lægger vægt alene på skildringen af de objektive sociale forhold, så bearbejder forfatteren den individuelt begrænsede oplevelse af disse forhold. Imellem de to parter står litteraturforskeren som den formidlende instans: „i forhold til litteraturstudiet galder det om at finde frem til de omstændigheder, der har været bestemmende for oplevelsen af de sociale forhold, og ikke blot dem, der har været bestemmende for de sociale forhold selv «. $^{10}$

Det er et synspunkt som her skal gøres til basis for en nærmere bestemmelse. Det ligger jo nemlig implicit i Peter Madsens fremstilling, at beskæftigelsen med de objektive, økonomisksociale forhold i sig selv tenderer mod en objektivering, der risikerer at fremstille historiens gang som udslag af en overmenneskelig, autonom mekanik. En sådan forståelse af de objektive forhold synes at ligge til grund, når Bonde Jensen i Litteraer arkaeologi f.eks. skriver, at »historien har dog vist at den menneskelige faktor kan spille ind $\mathrm{i}$ den $\emptyset$ konomiske proces, den har bl.a. i mange år formået at forhale det kapitalistiske systems snarlige sammenbrud « (183). Herved grundmures modsætningen mellem subjektivt og objektivt og der bygges videre på den mystifikation af kapitalens bevægelser, som Marx netop brugte sit 
hovedværk på at demaskere. Brugsværdiens forvandling til bytteværdi, bytteværdiens til penge, pengenes til merværdi og mervardiens til kapital kan hver gang tage sig helt okkult ud, men det ufattelige pedanteri, som leder læseren igennem Kapitalen, går dog netop ud på trin for trin at afsløre de mystiske forvandlinger som menneskeskabte, subjektivt forståelige foregange. At der i hælene på Marx er kommet en hel hær af kapitallogikere, er Marx ganske vist ikke selv uden skyld $i$, for så vidt som han havde en dæmonisk fornøjelse ved at fremstille de kapitalistiske sammenhænge som tilsyneladende objektive foregange, i bl.a. en religiøst farvet metaforik.

Mens faren ved den isolerede beskæftigelse med de objektive sociale forhold ligger $\mathrm{i}$ elimineringen af det erkendende subjekt selv, så synes risikoen ved beskæftigelsen med litteraturen som udtryk for oplevelsen af de sociale forhold at være undertrykkelsen af den objektiveringsproces, som er forbundet med det kunstneriske udtryk. »Uden nøjere studier vil man næppe komme til erkendelse af de grundlæggende linjer og kræfter i den historiske udvikling, men uden en vis personlig indforståethed med mennesker $i$ andre situationer end ens egen, vil de mennesker, hvis handlinger har drevet historien, forsvinde ud af den og kun historiens gang vil være tilbage «, ${ }^{11}$ skriver Peter Madsen, og synes i den følgende fremstilling at identificere den personlige indforståethed, som også kaldes det umiddelbart folelsesmassige forhold, med den kunstneriske fremstilling.

Det er dog nok værd at fastholde, at selv den mest naive kunstneriske fremstilling forudsætter et radikalt skel mellem det umiddelbart følelsesmæssige forhold og forfatteren. Det ligger allerede i den litteratur-tekniske term: den objektive fortæller, som i sin alvidenhed kender til det, intet jordisk menneske kender til. Dette skel kan i f.eks. den selvbiografiske roman udvikles til helt uanede grader af raffinement, som tilsyneladende lader den objektive fortæller totalt forsvinde; men under alle omstændigheder afhænger den erkendelse, som udfoldes, ikke af i hvor høj grad sociale institutioner kan siges at være udtómmende beskrevet, men af de funktionssammenhænge hvori de udtrykkeligt eller 
underforstået indgår. Erkendelsesgraden afhænger blandt andet af modsætningen og forbindelsen mellem på den ene side de fiktive personers oplevelse af sig selv og deres omverden, på den anden side den samlede handlingsgang, som er de objektive forholds udtryk i fiktionen. Det er i den forbindelse vigtigt at huske på, at de sociale forhold ikke kun er noget, som individet støder på udenfor sig selv i den samfundsmæssige omverden, men at de fra begyndelsen indlejres som subjektive bestræbelser i kraft af de socialisationsprocesser, som styrer individet livet igennem via diverse rosende og mishagsytrende instanser. Det objektive må $i$ den sammenhæng siges at være den del af det subjektive, som giver sig tilkende gennem adfærd, snarere end gennem meninger, gennem bevidsthedsformen, snarere end gennem bevidsthedens indhold.

Det drejer sig altså ikke om to modsatrettede bestræbelser, som om beskæftigelsen med de sociale institutioner førte ind i en stadig st $ø$ rre kollektivitet, mens beskæftigelsen med de kunstneriske udtryk mundede ud i det isolerede, enestående og usammenligneligt individuelle. Det kan udmærket være tilfældet, men må så også regnes for fejludviklinger af en samlet bestræbelse, som går ud på at oplede og erkende, hvor og hvordan socialiteten virker og er.

I sin artikel om »Humaniora i støbeskeen «, som beskæftiger sig med nogle af disse emneområder, foreslår Aage Henriksen som et muligt, tværfagligt problemfelt afklaringen »af autoritetsforholdet mellem det hverdagslige subjekt, som vælger og overvejer, har erfaringer og meninger, og det teoretiske subjekt, som ved metodens hjælp skiller sig ud af sin daglige virkelighed «. ${ }^{12}$ Her er skellet mellem subjektivt og objektivt altså formuleret som et skel $\mathrm{i}$ det individuelle subjekt, som et overordnings-underordningsforhold, der ikke uden videre er givet. Det er jo for eksempel - som det i sin tid blev hævdet - meget vel muligt at erkende de objektivt kvindeundertrykkende mekanismer i det borgerligtkapitalistiske samfund og fortsat lade kvinderne lave te til revolutionen. Det teoretiske subjekt, som efter teorien skulle være overordnet, viser sig ofte som langt svagere og betydeligt mere 
indskrænket end det hverdagslige, der er al erkendelses prøvesten og kilde.

Det er i den sammenhæng jeg gerne har villet fremhæve Bonde Jensens Carlsberg-bog som, hvis ikke forbilledlig, så i hvert fald et eksempel til efterfølgelse. Hvad bogen på overbevisende måde demonstrerer er jo, hvordan de objektive sociale forhold er virksomme $\mathrm{i}$ selve den subjektive motivering, og den demonstrerer det $i$ en praksis, som selv nedbryder modsætningen mellem erkendelsen af de objektive forhold og den umiddelbare følelsesmæssige oplevelse af dem. Det g $\phi \mathrm{r}$ den blandt andet derved, at den henter rammerne for en beskrivelse af et epokalt skred fra den sfære, som normalt er forbeholdt det kunstneriske udtryk: den primære socialisations rum, familieforholdet. Her er meddelelsesform og erkendelsesform identiske, nemlig i kraft af den bevidste stilisering af det konkrete til det eksemplariske. Ved at benytte sig af fader-s $\varnothing$ n konstellationen i stedet for af abstrakter som feudal og borgerlig, lader det sig gøre at skabe erkendelsesformer, som på en gang forbinder og adskiller: forbinder f.eks. den primære og den sekundære socialisation og samtidig adskiller dem ved at vise dem som funktioner af henholdsvis ældre og yngre samfundsformer. Det skal belyses ved hjælp af et sidste eksempel fra Carlsberg-bogen.

Situationen udspiller sig et godt stykke tid efter at bruddet mellem far og s $ø$ er blevet definitivt. I flere år har de ikke talt med hinanden, alene gammelfruen, Carls mor, fungerer endnu som tilforladelig go-between imellem de to. Det er søndag og den 40-årige Carl sidder som brygmester og husfader med kone og børn ved det sædvanlige, overdådigt dækkede frokostbord, da der kommer besked om at gammelfruen kommer på visit. Igennem hele sin barndom har Carl været vant til hjemme i de prægtige, romersk udsmykkede marmorsale at spise vandgr $\varnothing \mathrm{d}$ og klipfisk, som hans far anså det for sømmeligt: „Da man opdagede at gammelfruen var $\mathrm{i}$ anmarch beordrede Carl alle assietterne med de lune retter og det høje pålæg ned under bordet. Hans mor skulle ikke have lejlighed til at se deres flothed og plapre ud med det derhjemme. Da gammelfruen kom ind stod 
der på bordet kun et yderst spartansk måltid som svarede til den sparsommelighed, som J. C. Jacobsen var ber $\varnothing \mathrm{mt}$ for at sætte pris på (48).

Situationen er ikke bare guld værd. Den er også anskuelig, sprængfuld af skjulte modsætninger og et kosteligt koncentrat af Max Webers hovedværk om den protestantiske etik og kapitalismens ånd.

\section{Den kritiske videnskab}

I lyset af disse mellembestemmelser skulle det også være muligt lidt nøjere at definere den formidlerrolle mellem subjektivt og objektivt, som kan tilkendes en kritisk-historisk videnskab.

Til den ene side melder den sociale virkelighed sig i den kunstneriske fantasi som produkt af den individuelt-kropsbestemte, fysisk-sociale virkelighed. Til den anden side erkendes den i sin almene objektivitet via intellektuel abstraktion fra alle individuelle begrænsninger. Den kritisk-historiske videnskabs opgaver må da ligge $i$ til den ene side at erkende de kriterier, som ligger til grund for den konkrete kunstneriske udfoldelse, til den anden side at konkretisere de objektive forhold i deres historiske bestemthed. Det drejer sig ikke om at tage lidt hist og lidt her og flikke det sammen til en helhed, men om at udfolde den tredie mulighed, som ligger $\mathrm{i}$ en anskuende tankning.

Hvis det lader sig gøre at udskifte associationerne til Vilhelm Andersen med en tilknytning til Bonde-Jensens Carlsberg-bog, kunne man meget vel sige at en anvendelig litterær metode er en historisk-biografisk. I stedet for på forhånd at afvise den personfiksering, den hang til identifikation med enkelt-mennesker, som slår én imøde fra samtlige massemedier, hvad enten det drejer sig om ugeblade, aviser eller TV, så kunne man vælge at anerkende det legitime $\mathrm{i}$ behovet ved at demaskere det individuelle som de overindividuelle kræfters mødested.

Af den taktik følger en række konsekvenser. For det første at den biografiske synsvinkel på ingen måde, som tilfældet er med Carlsberg-bogen, behøver at være bundet til den sociale magtpyramides top; den kan, som Jytte Borberg har demonstreret det 
i Eline Besser-bøgerne, med lige så stor socialhistorisk gevinst knyttes til dens bund. For det andet kan litteraturhistorikeren ikke uden videre forudsætte forfatteren som objekt for sit studium. Han bør klogeligt være forberedt på, at det værk han $\phi$ nsker at sætte sig ind $i$, kan være produkt af en bevidsthed, som er mere omfattende end hans egen, og altså kan vende op og ned på det indbyrdes forhold, så at læseren i stedet for subjekt bliver objekt for den erkendelse, forfatteren har udfoldet i sit produkt. Heri er der ikke noget mystisk, for så vidt som den foreslåede tredeling mellem fantasi, kritik og intellektualitet ikke kan opfattes som nogen absolut typologi. Ligesom det stykke tilsyneladende virkelighed, der kommer til udtryk gennem den kunstneriske fremstilling, kan være tegnsprog for en højt kompliceret abstraktionsproces, sådan kan også de tilsyneladende mest blodløse abstraktioner, for den læser som er $i$ stand til at give begreberne krop, være af indgribende prægnans. Under alle omstændigheder drejer det sig om at etablere og at opfatte det sprog $i$ sproget, som er den uomgængelige forudsætning, hvergang en tidsalders normalbevidsthed og -illusioner skal overskrides.

\section{HISTORIEN}

\section{Formynderbegrebet}

Hvis det er rigtigt, at der med kunsten som medium kan udfoldes former for erkendelse af samme (eller altså større) autenticitet som indenfor de humant-videnskabelige fag, så betyder det hermed ikke, at kunstneren er hejset op på sin gamle inspirations-piedestal igen, men at han indgår som parthaver $i$ et fælles foretagende. Han kan læses og lære fra sig, henrykke og kritiseres. Der kan argumenteres med ham og imod ham, hvis blot man er opmærksom på ikke at gøre en indbyrdes uenighed til et spørgsmål om kvalitet.

Det er en sådan form for fundamental ligestilling jeg synes mangler i Bonde Jensens Litterar Arkaologi. Den kritiske fornuft er - ikke sat ud af spillet - men gjort til umyndigt tjenende 
legitimations-instrument for ikke det fælles, men Villy Sørensens bedste.

Unders $\phi$ ger man Formynderfortcellinger på baggrund af det foregående hovedafsnits mere teoretiske bestemmelser, kan man jo godt danne sig et begreb om, hvilket udsnit af den objektive historiske virkelighed der indgår $\mathrm{i}$ disse fortællingers univers. Set $\mathrm{i}$ forhold til skema-modellens tre grundstørrelser kan det om Formynderfortcellinger fastslås: 1 , at de savner relation til de historiske produktionsforhold og -redskaber. Den materielle virkelighed indgår generelt kun som spejlfunktion i forhold til den subjektive synsvinkel, hvorfra næsten alle fortællinger er fortalt. 2. At de historiske bevidsthedsformer alene kommer på tale $\mathbf{i}$ deres nutidige skikkelse, nemlig som en gennemgående polaritet mellem på den ene side en vågen-bevidsthed, som er gold, intellektuel og ude af stand til at forbinde sig selv med sine handlinger, og en drømme-bevidsthed, som er fremmed, skræmmende og mystisk-seksuel; en polaritet, som også kan formuleres som modsætningen mellem voksent og barnligt. 3. At fortællingernes historiske ambition koncentrerer sig om fremstillingen af det sociale hierarki: det er formynderforholdet i dets subjektive og dets objektive skikkelse der er målestok for den psykens historie, som Villy Sørensen har angivet som sin bogs emne.

Spørgsmålet må så være, hvilken form for historicitet man kan tilkende formynder-begrebet. I den sammenhæng er Bonde Jensen overordentlig fåmælt. I stedet for at unders $\varnothing$ ge dets historiske funktion, tager han det straks i nutidens overf $\varnothing$ rte betydning: »om en værge man må værge sig imod, en autoritær personlighed eller hyppigere en upersonlig autoritet« (169), og på den måde kan han hævde: »Villy Sørensen graver sig ned gennem tiderne til de ældste lag i den skriftligt overleverede kultur og gør gammelt til nyt i formynderbegrebet idet han afdækker den skjulte forbindelse mellem gammel personlig umyndighed og moderne anonymt formynderi« (170).

Sagen er jo, at mens formynderbegrebet udmærket kan fungere som et kodeord til de sidste årtiers samfundsdebat og til den ledelseskrise, som har gjort sig gældende på alle samfundets ni- 
veauer, så er det den dårligst tænkelige nøgle til en forståelse af de sociale magtforholds historie. Som Bonde Jensen selv gerne gør det, kan man slå op i ODS under ordet formynder og læse: "person, som (i forældres sted) tager sig af en umyndigs ( $\varnothing$ konomiske og personlige) forhold $\ll$. Til grund for ordets historiske betydning ligger således implicit et begreb om en fundamental lighed mellem umyndig og formynder, som er forelфbigt suspenderet, nemlig indtil myndighedsalderen er nået. Formynderen er ikke alene sat til at bestemme i andres sted, men han er også bestemt til at blive sat fra styret, når hans myndling når skelsår og alder.

Vælger man nu at generalisere over fortidens magt-hierarkier udfra dette begreb, så kommer man samtidig til at almengøre en historisk specifik bestemmelse. Ikke alene anfægtes overordningsunderordningsforholdet hermed som den elementært givne samfundsrelation, skønt den dog har været det indtil for relativt nylig, men formynderbegrebet løber samtidig fuld af en underliggende, ganske revolutionær bestemmelse, nemlig ideen om den universelle menneskelige lighed. På den ene side forflygtiges det, at formynderbegrebet kun rummer historisk konfliktstof indenfor den $\emptyset$ verste lille trekant af det samlede sociale hierarki, nemlig de kongelige/hofadelige kredse, hvor formynderens usurpering af magten kan anfagtes af den indbyrdes slagtsmassige lighed, som betyder: den lige ret til potentielt at regere over alle de andre. På den anden side fortrænges det ganske afgørende faktum, at ideen om en menneskelig lighed på tværs af slægts-, klasse-, kønsog raceforskelle, langt fra at kunne anvendes som en selvfølgelig, halvt bevidst målestok for historiske foregange, tværtimod repræsenterer en kulturel nyskabelse af relativ ung dato. Kan den måske siges at vare kommet til verden sammen med Paulus' udlægninger af relationen mellem Jesus og Kristus i Det ny testamente, så er kravet om en samfundsmæssig virkeliggørelse af ligheden, ikke bare i Guds rige, men i denne verden selv, ikke meget ældre end den franske revolution.

Af formynderbegrebet bliver Bonde Jensen således forført til at vende fuldstændig op og ned på den historiske udvikling, idet 
han hævder at »dobbeltbilledet af formynderen og myndlingen er det kunstnerisk forarbejdede udtryk for den faldne, den splittede, den fremmedgjorte, massemennesket « (171). Når han umiddelbart forinden identificerer dette dobbeltbillede med »bruddet på fællesskabet med Gud og medmennesket «, så må det heroverfor hævdes, at det faktisk forholder sig lige omvendt. Jo længere man går tilbage i tiden, desto mere ubetvivlelig bliver overordningsunderordningsforholdet eller altså forældre-barn relationen som den generelle samfundsmæssige bestemmelse. Den er netop udtryk for den hele, usplittede tilværelse, forud for bruddet med gud og medmenneske, hvad der også med al ønskelig klarhed fremgår af syndefaldsberetningen i 1 . Mosebog. Faldet består netop i at mennesket tiltager sig en magt og en indsigt, som alene tilkommer faderguden. Og det udvirkes blandt andet fordi slangen hvisker »formynderi« om barneforholdet i menneskets фre. Omvurderingen af denne begivenhed fra forbryderisk syndefald til første etape $i$ en fri handling, hvis endemål er retableringen af paradiset på den emanciperede bevidstheds præmisser, fandt da også først for alvor sted i løbet af det 18. århundrede, som skabte forudsætningerne for det borgerlige samfunds retfærdighedsbegreber. ${ }^{13}$

\section{Genredefinitioner}

Jeg tror ikke på, at Villy Sørensen skulle være uden kendskab til dette elementære forløb. Når det alligevel kommer til at tage sig sådan ud i Bonde Jensens fremstilling, skyldes det, at Formynderfortallinger med djævlens vold og magt skal gøres til alt muligt andet end det de er. De skal være et stykke socialhistorie mere end 10 år før begrebet blev opfundet, de skal foregribe den dokumentariske genre, sk $\phi$ nt deres forhold til citatmaterialet $i$ ét $o g$ alt er modernistisk; de skal endog repræsentere løsningen på romanens krise, udfra den præmis at de ikke gør individet, men individets problemer til hovedperson for fremstillingen. Hvor mange novelle- og digtsamlinger, leksika og stikordsregistre kan herefter ikke præsenteres som løsninger på romanens krise. Der er ikke den vanskelighed, som ikke kan ryddes af vejen, når det gælder hævdelsen af Formynderfortallingers totale historiske 
holdbarhed; selv springet fra middelalder direkte til nutiden med udeladelse af samtlige de århundreder, hvor alle afgørende forandringer fandt sted samt det totale fravær af kvindernes undertrykkelses-historie, lader sig bortforklare, selvom jeg nødig vil forklare hvordan. Man kan ikke undgå at få fornemmelsen af, at Villy Sørensens fortællinger nu en gang skal være (frem)tidssvarende, ganske uanset om der så også skal holdes ophørsudsalg på ti års litteraturvidenskabelige landvindinger.

Ind imellem Bonde Jensens mange, fantastiske vildskud mener jeg også der findes en karakteristik af Formynderfortcellinger, som rammer plet. Den stammer fra fællestitlen på en samling kvartsiders historier, som ikke har været optrykt siden Villy Sørensen i 1961 offentliggjorde dem i Vindrosen. De er alle opbygget som uendeligt formindskede, ironisk-anekdotiske udtræk af omfattende begivenhedsforløb, udfra devisen: $s$ To unge mennesker havde så stor glæde af at se på hinanden at deres øjne voksede og blev så store at det forekom dem mere og mere uoverskueligt at se hinanden i øjnene. Så skiltes de i stor rastløshed og kunne siden med deres store $\emptyset$ jne gennemskue altings forfængelighed «. ${ }^{14}$ Når Bonde Jensen foreslår at Formynderfortallinger rubriceres under samme fællesnævner som disse såkaldte genfortcellinger, så mener jeg man heri har en mulighed for at komme frelst igennem det tætte minefelt af litterære og alle mulige andre allusioner, som er en af de mere afskrækkende ting ved Formynderfortallinger. Selv opregner Bonde Jensen ikke alene alle de genrer, Villy Sørensen har taget i brug: „Myte, eventyr, drøm, fabel, gåde, krønike, brev, dialog, legende, prosadigt, filosofisk utopi (173), men også diverse forudsætninger indenfor »historie, religionsvidenskab, mytologi, psykologi, pædagogik, biologi, sociologi, politik, litteraturvidenskab og sprogvidenskab, 'futurologi' " (171) samt tekstcitater fra »Bibelen og de græske myter over Seneca og Sveton til folkeviserne, Silvio Piccolomini, Shakespeare og H. C. Andersen - og til strengere videnskabelig litteratur « (172).

Når denne højst barokke lærdomsopregning alligevel højst er barok, hænger det sammen med, at den ikke skal tages så alvor- 
ligt. Det er rigtigt, at Formynderfortallinger forudsætter en historisk dannelse, som om tyve år sandsynligvis vil tage sig helt dinosaurisk ud. Men dog ikke i højere grad end at de fleste (af det mindretal), som har gennemgået et samlet uddannelsesforl $\emptyset b$ fra før 13-skalaens indførelse, på et eller andet tidspunkt har været $\mathrm{i}$ ber $\phi$ ring med samtlige fortællingernes associationsflader.

Det forholder sig jo ikke sådan, at Formynderfortallinger g $\phi \mathbf{r}$ sin læser klogere på det 2000-årige tekstudvalg, som fortællingerne forudsætter bekendt. Meningen er ikke, at man skal gå hen og gen- eller nylæse de pågældende tekster og bruge dem som tolkningsn $\emptyset$ gler. Gør man det, løber man vild i en labyrint af associationer, som Bonde Jensens egen fremstilling så udmærket bevidner. Hvad der forudsættes bekendt, forudsættes netop bekendt i sin traditionelle skikkelse, og det er med den Formynderfortallinger holder historisk opg $\varnothing$ r. Således gøres Paulus personligt ansvarlig for en seksualitetsopfattelse, som han delte med resten af sin samtid, mens alle de træk, der skiller ham fra hans forudsætninger, slet ikke berøres. Ligesådan fremdrages som repræsentant for den feudale magt så eksotisk en person som Frederik III, der velnok er en af de mindst repræsentative kejsere, som overhovedet lader sig oplede, men netop derved egner han sig fortrinligt til at sætte den feudale fader-kliché, som vi idag forbinder med middelalderen, i relief. Derfor ville det også være helt hen $\mathrm{i}$ vejret at rette den slags historiske indvendinger mod fortællingerne. Det er ikke fortiden, men de traumer af psykologisk og social karakter, den har efterladt i nutiden, der er Formynderfortallingers emne. Historien er, med Villy S $\phi r e n-$ sens egen formulering, sikke længer en betegnelse for det der er sket, men for det der sker« (139). Hvad der holdes rettergang over, er nutidens afmagt som produkt af fortidens fordomme, og så er det af mindre betydning, om der rettes smed for bager, Paulus for dronning Viktoria, Frederik III for Hilmar Baunsgaard. Der fortælles ikke nogen ny historie, men de gammelkendte genfortælles, ironisk-anekdotisk, med en vrangvendt pointe, som under den vittige overflade g $\varnothing \mathrm{r}$ samlingen til, hvis ikke en tragisk, så en højst galgenhumoristisk bog. 
Denne opfattelse af Formynderfortallinger mener jeg med lethed kunne efterprøves på de tre legender, glashistorien, Skrigeren eller Fuglen i jomfruham. Men jeg foretrækker at eksemplificere den på den mindre indlysende Fremtidshistorie, som udgør kulminationen på Bonde Jensens fremstilling. Gennemgangen kommer til at samle sig om de fire grundelementer i Ødipus-myten: profetien, forbytningen, faderdrabet og incesten, der er dem såvel Villy Sørensens fortælling, som Bonde Jensens udlægning har som hovedemne. Påstanden er altså, at disse grundelementer indgår i Villy Sørensens fortælling i deres traditionelle skikkelse: de forudsættes bekendt, men i virkeligheden transporterer de betydningssammenhænge, som fortællingen ikke alene er ubekendt med, men som også giver handlingsgangen en mening ganske modsat den, Bonde Jensen læser ud af fortællingen. Konkret dokumenteres denne pointe $i$ en nærlæsning af den beslutningsproces, som gennemspilles i opgøret mellem sønnen Filius og hans præsident-fader. Hvad Bonde Jensen her opfatter som den frie, emanciperede handlings udspring, ser jeg som totalt determineret af de objektive sociale forhold, der i fortællingen er delvis iklædt mytisk skikkelse.

\section{Et eksempel: Tronarvingen}

Selve den Sørensen'ske genre: genfortallingen, kan defineres som et resumé, der i sin koncentration lægger vægten på det paradoksalt-sammenhængende, logisk-n $\emptyset$ dvendige $i$ et tilsyneladende uigennemskueligt kompleks af begivenheder. Hvis man nu fastholder, at den menneskelige tilværelse er sammenvævet af frihed og nødvendighed, så ligger nødvendigheden begravet $\mathrm{i}$ begivenhedsforløbet og friheden i gennemskuelsen af det, og de to mødes i ordspillet, som sprogligt formulerer det tvingende, men samtidig tvinger læseren til at le, - som tilfældet er med de to elskende, der ser hinanden så dybt $i \emptyset j n e n e$, at de sidenhen kan gennemskue altings forfængelighed.

Om forholdet mellem frihed og nødvendighed handler $E n$ fremtidshistorie. Det lyder abstrakt og det er det sådan set også. Førend man kan gå ind i historien, er det nemlig nødvendigt at 
gøre sig klart, at den bygger på et sæt spilleregler, der er abstraheret fra, hvad vi plejer at opfatte som virkeligheden. For det første skal vi anerkende muligheden af en samfundsmaskine, hvorefter det lader sig gøre at forudberegne det enkelte menneskes skæbne og indrette sig derefter. Dernæst godtage, at individets skæbne kan være restløst og tilfredsstillende udtømt, hvis der er sørget for dets placering, arbejdsmæssigt og kønsligt; at man altså har det godt, hvis man får det godt. For det tredie at nogle er bestemt til at være urmagere, nogle til marathonløbere og nogle til gadedrenge, mens en anden kan være bestemt til at slå sin far ihjel, gå i seng med sin mor og ende som præsident. Samt endelig at disse bestemmelser tilsammen kan rubriceres under begrebet nфdvendigheden.

Kort fortalt handler historien om to gamle arvefjender, som har kæmpet om magten i landet. Den ene, som er præsident, har altså vundet over den anden og indrettet et samfund efter de retningslinier, som før blev skitseret. Ved historiens begyndelse har han fået en arving, ved hvis fødsel den store EDB-maskine har forudsagt de nævnte forfærdelige og forjættende kendsgerninger. Skrækslagen undfanger præsidenten den idé at slå to fluer med ét smæk: først og fremmest at redde sig selv fra at blive slået ihjel af sin søn, men samtidig at få udryddet sin hovedmodstander, Filip Rose, som fortsat går rundt og mistænkeliggør det nye regime og beskylder »forudbestemmelsen " for blot at være en objektiv forklædning af præsidentens private interesser. Ved en manipulation, som går ud på at forholde andre viden og forklæde egne motiver, lykkes det præsidenten at få Filip Rose til at overtage sønnen Filius, som af sin nye og intetanende far opdrages til samfundsomvælter og åndelig arving.

Mens præsidentens system bygger på (også hans egen) hengivelse til en bestemmelse, som er truffet på højere sted, bygger Filip Roses på, at man skal bestemme alting selv og ikke lade sig noget byde. Resultatet af de to fædres manipulationer bliver en søn, som er i opposition ikke alene til sin (sted)far, men også til hele det omgivende samfund, som han på grund af sit manglende fødselsnummer er afskåret fra at komme ind i. Jo ældre 
han bliver, des mere isoleret bliver han, og da det viser sig, at han også er afskåret fra at gifte sig med den pige, han er blevet forelsket i, beslutter Filius sig for dels at sende sin elskede, Filia, et afskedsbrev, dels at skyde sig selv en kugle for panden. Han får gjort det første, men afbrydes midt i det andet af præsidentfruen Asta, som er kommet for at finde sin søn og tror det er en helt anden end Filius. Af sorg over hvor dårligt det er gået sønnen, har Filip Rose nemlig netop afsløret hans identitet for alt folket, som nu stormer ind for at hylde arvingen. I mellemtiden har mor og søn intetanende været i seng med hinanden og er blevet overrasket midt $i$ det hele af den hjemvendende Filip Rose, som får et slagtilfalde ved synet og dør. Derpå begår også præsident-fruen selvmord, ligesom kæresten Filia gør det, ved modtagelsen af Filius' afskedsbrev. Og sønnen selv ender med at remplacere sin far $\mathrm{i}$ embedet som præsident, efter et opg $\phi \mathbf{r}$ på pistol, som om lidt skal omtales lidt nærmere.

Om de to fædre hedder det i Littercer arkaologi: „Sønnens biologiske fader repræsenterer nødvendigheden, han er præsident og et med sit embede og derfor uden navn. Plejefaderen repræsenterer friheden « (140), skriver Bonde Jensen og det er ikke svært at gætte, hvem han holder med. Det er bare underligt at han gør det. Ved at placere sympatien hos Filius og hans plejefader placerer han den hos de to, som historien igennem forbliver totalt uvidende om de objektive sociale forhold, de er marionetter for. Filip Rose dør i en fuldkommen illusion om sin egen skæbne og præsidentens rolle i den; og da Filius til sidst får indblik i sammenhængen, drager han en række konklusioner af sin indsigt, som klart dokumenterer, at han ikke har forstået et pluk af det hele.

Mens det aldrig går de to som de havde tænkt sig, og deres handlinger konstant løber fulde af konsekvenser, de ikke havde forudset, så findes der inde $\mathrm{i}$ historien én person, som ikke alene kender hele historien fra begyndelsen, men ovenik $\varnothing$ bet får den m $\varnothing$ bleret om efter sit eget hovede. Det er præsidenten. Det viser sig jo, at han ikke er mere ét med sit embede end at han prioriterer én ting højere end alt andet: sit eget liv. Og faktisk er alle 
historiens indviklede intriger funktion af den ene hensigt hos prasidenten: at få reddet sit eget skind uden at nogen bliver klar over, at det er det, han vil.

Alting tyder imidlertid på, at præsidenten ikke alene fører fortællingens fiktive personer bag lyset, men også såvel dens fortolker som dens forfatter. Det bemærkelsesværdige er jo, at den temmelig magre pointe kommer til at afsætte den ene mere vidtgående fortolkning efter den anden hos alle præsidentens omgivelser, som dør, tager deres liv, bliver gale eller præsidenter, uden at ane hvorfor de gør det. Således ender præsidentens dødsfjende, Filip Rose, med at anse ham for det mest uegennyttige og selvopofrende af alle mennesker, og dør af hjerteslag i den overbevisning, at han alene bærer al skyld, ikke alene for at det er gået hans plejesøn så dårligt her i verden, men også for at sønnen er endt med at ligge på gulvet og elske sin mor. Og hvad Filius angår, så slutter han ikke alene med at kaste pistolen og falde præsidenten grædende om halsen, men begynder også at lave om på hele samfundet for at det ikke skal gå andre som det er gået ham selv, skønt det aldrig ville være gået ham sådan, hvis ikke han af fædrene var blevet forhindret $i$ at leve $i$ overensstemmelse med samfundets indretning og sin egen bestemmelse.

\section{Fader og sфn}

Som før nævnt er En fremtidshistorie ikke den eneste historie, der handler om fremtiden i Formynderfortcellinger. Det gør En glashistorie også. Ifølge Bonde Jensen er forskellen på de to historier identisk med forskellen mellem nødvendighed og frihed: »Hvor perspektiveringen mod fremtiden i den første (indledende) fremtidshistorie er af logisk art, er den i den sidste tillige af etisk art. Hvor udviklingen $i$ den første så at sige deduceres ud af nutiden og fortiden, fremgår den $i$ den sidste tillige af en viljesytring med basis i udforskningen af nutid og fortid « (17).

Denne opfattelse af det etiske som noget specielt kvalificeret, der står i ekstraposition til den kendte historie, skal her udsættes for en lidt nøjere granskning. For læseren af En glashistorie giver det umiddelbart slet ingen mening, for historien er befol- 
ket af lutter mennesker, der bevæger sig i »etiske« kategorier og som uafbrudt bebrejder hinanden det forkerte eller roser hinanden for det gode og rigtige, og hovedpersonen selv er en yderst moralsk anlagt karakter. Bonde Jensens særlige brug af ordet etisk lader sig kun forstå i lyset af den centrale beslutningssituation i En fremtidshistorie, der handler om den gamle eksistentialistiske drøm om at belure friheden i dens tilblivelsesøjeblik. Meningen med den voksende isolation, som hovedpersonen Filius udsættes for $\mathrm{i}$ fortællingens $1 \varnothing \mathrm{b}$, er jo at få ham drevet derud hvor intet er tilbage og derfor intetheden mirakuløst slår om $\mathrm{i}$ sin modsætning: friheden. Det sker i første omgang, da Filius står med pistolen mod tindingen og skal til at trykke af, det gentager sig i den følgende incest-situation, men kulminerer i Filius' opgør med sin far, præsidenten.

Det finder sted på et tidspunkt, hvor præsidenten anser det for nogenlunde sandsynligt, at Filip Roses død var udtryk for den del af forudsigelsen, som gjaldt drabet på faderen. Derfor anser han det også for forsvarligt at afsløre for Filius, at det liv som han har troet udenfor normen og enhver sandsynlighed, $\mathrm{i}$ sandhed har været normeret lige fra begyndelsen. I første omgang nøjes præsidenten dog med at fortælle ham, at det ved hans fødsel blev forudsagt, at han skulle være sin fars efterfølger: "Din senere stedfar, Filip Rose, der dengang var min modstander, anede at du var forudbestemt til præsident og forkyndte for folket at det ikke kunne gå rigtigt til. Af angst for at folket skulle vende sig mod dig, måtte jeg afstå dig, Filius, som var din mors og min største glæde« (FF 251), betror præsidenten ham og udstafferer sig altså med det samme smukke motiv, som Filip Rose endte med at tilskrive ham. Hertil indvender Filius, at hvis han virkelig var forudbestemt til at blive præsident, hvorfor $i$ alverden var det så nødvendigt at foretage en forbytning, så at han blev skilt fra sin mor og spørger truende: »Troede du ikke selv på forudbestemmelsen, var du bange for at miste din magt, hvis folket troede på Filip Rose? « (FF 252), og pludselig trækker han en pistol op af lommen. Rædselsslagen svarer præsidenten, at han ved at skille Filius fra sin mor netop medvirkede til at få den 
forudsigelse til at gå i opfyldelse, som Filius mistror ham for ikke at tro på.

»Det blev måske også forudsagt at jeg nu skyder dig en kugle gennem hjertet (FF 252), råber Filius, hvortil præsidenten gisper: »Ja - også det blev forudsagt«.

På dette sted måtte man nu have ventet, at hele Filius' hidtidige skæbne, idet der pludselig faldt helt nyt lys over den, var brudt op i ham og at han i raseri over sit eget forkvaklede liv og Filias, Filips og præsidentfruens meningsl $\varnothing$ se d $\varnothing \mathrm{d}$ havde tømt hele magasinet i hjertet på krysteren, bedrageren og den virkelige morder, mens han råbte: »Og bare for at redde dit eget sølle skind planlagde du at lade min far og min mor, øh, jeg mener Filip og Filippa, undgælde for den skæbne, som tilkom dig! «.

Men det hverken siger eller gør Filius. Så meget søn er han nemlig af sin stedfar, at hvis det er forudbestemt, hvordan han vil handle, vil han bestemt ikke handle sådan. I stedet for bliver han sentimental og falder den mand om halsen, som han ikke har den ringeste grund til at nære sønlige følelser overfor, for så vidt som de to $\mathrm{i}$ hele hans hidtidige liv ikke har vekslet mere end tre ord: »Far! «, råber han Gud bedre det grædende, »og du troede at jeg ville myrde dig! « (FF 252).

Hermed er det værste overstået. Præsidenten kan tørre sveden af panden og sige pyhha: "Så var sandheden ikke så grum som jeg troede« (FF 253). Men midt i den påf $\varnothing$ lgende kærlige omfavnelse stivner Filius pludselig på grund af et sidste problem.

Kan han nemlig besynderligt nok finde trøst $i$, at præsidenten altså under alle omstændigheder har troet fuldt og fast på forudsigelsen (hvad han dog kun har, for såvidt som han har anset den for at være både blind og dum), så er den jo for hans eget vedkommende løgn, hvis ikke han myrder ham: „Hvis jeg myrder dig, er du uskyldig i min mors $d \phi d-o g$ i andre kvinders $d \varnothing d$ og mærkelige forsvinden. Men hvis jeg ikke myrder dig, så er det din skyld altsammen, og så har du fortjent at dø, for så er du morder« (FF 253).

Situationen minder til forveksling om Hamlet, der står med draget sværd bag ryggen af sin knælende onkel, men alligevel ikke 
kan få sig til at bruge det; for dræber han sin fars morder, mens han ligger og angrer ved alteret, så farer onklen jo lukt op i himlen, og hvad er hele hævnen så værd? På samme måde kunne Filius også have stået og viftet med pistolen resten af sit liv, i evindelig tvivl om hvorvidt han skulle skyde præsidenten af den ene eller hellere af den anden grund. Hvis altså ikke præsidenten havde været så venlig at komme ham til undsætning.

»Har jeg ret?«, spørger Filius nemlig rethaverisk præsidenten, som er parat til at give ham ret $\mathrm{i}$ hvad som helst, bare han ikke bliver skudt. »Og det er mig der selv bestemmer om du skal leve eller d $\varnothing$ ? « funderer Filius videre. »Ja, det er dig der bestemmer, " samtykker præsidenten. »Men så er jeg herre over forudbestemmelsen. Og så er jeg fri, « triumferer Filius, skønt man aldrig nogensinde f $\varnothing$ r eller siden har hørt om noget menneske, der var i stand til at skyde et andet for en sofismes skyld. Muligheden for at røre ved aftrækkeren har han i virkeligheden forspildt for flere replikskifter siden. Men bortset fra det, mangler han jo stadig en logisk grund til ikke at skyde præsidenten: skyder han ham ikke, er han herre over forudbestemmelsen, men skyder han ham, er han det vel ikke i mindre grad? Han kan skyde ham eller han kan lade være, det kan komme ud på ét. For alle andre end for præsidenten, som er så fornuftig ikke at argumentere med den gale person og $\mathrm{i}$ stedet hvisker: „Filius, du skal blive fri for mig, hvis ikke du myrder mig. Lad mig afgå som præsident $i$ stedet for ved d $\varnothing$ den« (FF 253).

\section{Fiktion og forfatter}

Mens det således lykkes præsidenten at klare frisag ved hjælp af et par ordspil, er Filius henvist til at hævne den fortid, han ikke fik hævnet på præsidenten, på hele samfundet. Fikseret i den overbevisning, at hans livs misère skyldes, at alle andre havde personnummer, mens han selv ikke havde noget, beslutter Filius, at personnummer-unders $\phi$ gelserne skal være frivillige. Da det vil medføre, at en masse andre sandsynligvis vil få de samme problemer som han selv, må han ikke alene iværksætte et kæmpe skolebyggeri til de nummerløse, men også indføre den lov, at alle 
skal have lov uhindret at forelske sig i hinanden, hvis de ellers to og to kan blive enige om det. Det manglede egentlig bare, at han også udstedte en forordning om, at en mor med god samvittighed kan gå i seng med sin $s \emptyset n$, hvis blot hun ikke ved, han er det.

At Filius lovgiver med henblik på at almengøre sit eget særpræg, fremgår klart nok af, at det er den ulykkelige kærlighedshistorie med Filia, han hele tiden har $\mathbf{i}$ tankerne. Man tvinges altså af historien til at stille det spørgsmål, om ikke hun netop var forudbestemt til at d $\varnothing$ ? Unders $\emptyset$ ger man omstændighederne omkring hendes selvmord, må det i hvert fald konstateres, at der i tiden mellem Filius skrev sit selvmordsbrev og indtil Filia modtog det, var et rimeligt spand af tid til at underrette hende om, at han stadig var i live. Selv undlader hun på ganske samme måde at opsøge Filius, død eller levende, førend hun kaster sig i floden. Hele skildringen af kærlighedshistorien synes da også at dokumentere, at den snarere hører evigheden end tiden til: Filia og Filius har kendt hinanden længe før de første gang $m \varnothing-$ des, de er romantisk bestemt for hinanden og ingen af dem drømmer om at overtræde de love, som forhindrer dem i den endelige forening.

Alting tyder imidlertid på, at der her er tale om en forudbestemmelse, som ikke tilfredsstillende lader sig forklare udfra fortællingens sammenhæng, men alene som et ubevidst arrangement fra forfatterens side. Med ubevidst menes: at der i fortællingen selv ikke findes noget tegn på, at det skulle være en selvmodsigelse, når Filius uddrager en samfundskritisk indignation af sin romantiske forelskelse. - Det er ikke først og fremmest Filius, men hans forfatter, som er romantikeren, nemlig i sin skildring af de tos kærlighed, og det har Filius naturligvis ingen chance for at gennemskue. Han må tro sig i sin gode ret til at få pigen og kan ikke vide, at Villy Sørensen netop har indsat ham i en kærlighedshistorie, som efter sit eget væsen er afskåret fra jordisk opfyldelse. Spфrgsmålet er altså bare, om Villy Sørensen selv ved det.

På lignende måde kan læseren heller ikke vide sig sikker på, 
hvorvidt præsidentens arrangementer er forfatteren fuldt bevidst: når fortællingen fra begyndelsen modstiller Filip Rose og præsidenten som repræsentanter for henholdsvis det frie valg og forudbestemmelsen, er ironien så på forfatterens eller alene på præsidentens side, når præsidenten ender med at fremstå som det eneste frie individ, for så vidt som det hele fortællingen igennem lykkes ham og ham alene at styre frelst igennem spillet af $n \varnothing d-$ vendighed og tilfældighed og at udnytte begge til sin egen fordel?

\section{6. Ødipus-komplekset}

Når Bonde Jensen kan kalde det kludetæppe af et samfund, som Filius ender med at indrette i slutningen af En fremtidshistorie, for en fuldgyldig realisering af det autoritetsfrie broderskab, så kommer det nok ikke så meget af Filius' konkrete forordninger, hvorom man næppe kan sige andet fornuftigt, end at de ligner en reduceret udgave af det danske samfund. Det stammer snarere fra, at Filius selv slipper uskadt igennem den Ødipus-historie, som $\mathrm{i}$ begyndelsen af Bonde Jensens fremstilling endte med Judas' selvmord. Som tidligere omtalt anser han En fremtidshistorie for at være en generel frelseshistorie for både Judas, Filius og Freud. Alting tyder imidlertid på, at der skal mere til at blive frelst end at sige, man er det. Det er ikke enhver der siger $\emptyset$ dipus, Ødipus, som også har løst sfinksens gåde.

En første forudsætning for at man med nogen ret kan tage myten $\mathrm{i}$ besiddelse må være, at man kan forbinde en mening med Ødipus' dobbelte forældrepar. Det kan man klart nok ikke i $E n$ fremtidshistorie, hvor såvel forestillingen om faderdrabet som samlejet med moderen hviler på et fuldstændig konventionelt og forvitret forældrebegreb.

Når det $\mathrm{i}$ den klassiske $\emptyset$ dipus-tragedie giver mening at skelne imellem på den ene side de forældre, vi plejer at kalde vores far og mor: dem som vi kender, som har ernæret os og opdraget os og dannet den konkrete basis for vores voksne eksistens, og på den anden side de forældre, som har avlet og undfanget os, så hænger denne skelnen sammen med et samfund, hvori begrebet slcegt udgør den grundlæggende realitet. Og realitet vil i den sam- 
menhæng sige, at slægtsrelationen var stærkere end den personlige relation, at stamme-identiteten var virkeligere end den individuelle jeg-opfattelse, at blodet var sandere end bevidstheden. Om den begyndende modsætning mellem disse to hidtil samordnede størrelser handler Sofokles' $\emptyset$ dipus-tragedie, og om følgerne af opbruddet fra en slægtsbestemt, nedarvet identitet handler store dele af de sidste 2000 års europæiske historie. ${ }^{14}$

I dagens samfund, hvor det personlige forældreskab fuldstændig har slået det biologiske af marken, når bortses fra juridiske grænsetilfælde som faderskabssager etc., giver det heller ikke umiddelbart nogen mening at basere en intrige på en sådan dobbelthed eller modsætning, med mindre man er i stand til at fylde begrebet: de biologiske forældre, med en anden, fornyet betydning. Men det er hverken En fremtidshistorie eller Bonde Jensens udlægning af den i stand til.

Hvis man i første omgang tager incest-situationen: samlejet med moderen, så hviler den påståede smerte, som opdagelsen af incesten skulle fremkalde, på aldeles konventionelle forestillinger. Der er for præsidentfruen $A$ sta ikke den ringeste grund til at begå selvmord, efter at hun har opdaget sin slægtsmæssige relation til den unge mand, hun lige har haft fornøjelsen af at elske, så meget mere som historien netop selv gør et stort nummer ud af, at den foregår $\mathrm{i}$ et samfund, hvor de sidste rester af arve- og slægtsforestillinger er udryddet. Hendes reaktioner er kun begribelige på baggrund af Sofokles' tragedie. Fru Astas ve-skrig låner helt fiktiv kraft fra Jokastes vanvittige rædsel over, at $\emptyset$ dipus insisterer på at afdække den skam, hun selv allerede kender.

For Filius' vedkommende har samlejet da også fremfor noget karakter af en manddomsprøve; han er dødpotent og føler det som selve frihedens øjeblik, hvad Bonde Jensen giver ham helt ret i: Filius er »blevet født påny - som mand. Der er grund til at frygte for hendes (Astas) liv som mor, - og andet liv har hun ikke levet « (161). Faktisk forholder det sig stik modsat: er der noget liv, hun ikke har levet, er det livet som mor. Men når Bonde Jensen først har fået fingre i et symbol, er han uden hensyn: moren har gjort sin pligt, moren kan dø. - Om incest er der 
under ingen omstændigheder tale. Havde Filius derimod kneppet englen Filia som han knepper den ukendte dame, kunne vi have talt om tingene.

På lignende måde forholder det sig med faderdrabet. Overfor hvilken instans i En fremtidshistories univers skulle Filius have følt sig skyldig, såfremt han havde skudt præsidenten? Fadermord er jo ikke først og fremmest drab af et menneske, men drab på en betydning som er mere værd end et menneskeliv (at Ødipus i tragedien engang på vej fra Delfi til Theben har slået en mand ihjel, er fuldstændig i sin orden, lige indtil det øjeblik hvor det bliver klart, at manden er hans fader).

Man kunne nu hævde, som Bonde Jensen $g \varnothing r$ det i begyndelsen af sin udlægning, at præsidenten repræsenterer nødvendigheden og at det er hans betydning. Men det er tydeligvis forkert: for det første gør præsidenten netop alt for at manipulere med forudbestemmelsen, så han bliver dens herre og ikke dens udtryk, for det andet havde Filius, såfremt han havde skudt præsidenten, netop fuldbyrdet nødvendigheden, så den i stedet for at blive sat ud af kraft, havde hævdet sin gyldighed.

Som tingene går, må man spørge, hvad man overhovedet kan forbinde med begrebet nødvendighed, når den udformes som det fantastiske påfund: forudbestemmelsen. Hvem indenfor fortællingens univers har bestemt, hvad der er forudbestemt? Ikke præsidenten, som henholder sig til, hvad der kommer ud af spåmaskinen. Heller ikke spåmaskinen, som henholder sig til, hvad der bliver puttet ind i den. Og slet ikke det individ, hvis skæbne skulle være bestemmende, uden at det selv hverken kan eller vil bestemme noget som helst: den enkelte får det netop som han/hun skal have det.

Man tvinges således til at gå bagom historien og fastslå, at den som bestemmer, hvad der forud er bestemt, ene og alene er forfatteren. På det sted, hvor i sin tid guderne var placeret, har Villy Sørensen hemmeligt placeret sig selv. Men han har gjort det som en vilkårlig, en upålidelig gud, der end ikke er i stand til at holde sit ord. Også i denne sammenhæng tærer En fremtidshistorie på en fuldstændig fiktiv forbindelse til et mytisk møn- 
ster, her: oraklet i Delfi. En forudbestemmelse, som ikke går i opfyldelse, er naturligvis ikke nogen forudbestemmelse. At anse den for en udvortes mekanik, som man frit kan vælge om man vil følge eller ej, og ikke som identisk med, hvad et menneske inderst er og vil, er at berøve forudbestemmelsen enhver mening. At mene, som Filius g $\phi r$ det, at præsidenten ikke er skyldig i Filips, Filippas, Filius', Filias og Astas skæbne, såfremt Filius skyder ham, er ren galimatias: når det er gået dem alle, som det er, skyldes det under alle omstændigheder præsidentens (og altså Villy Sørensens) behændige manipulationer med deres liv og uvidenhed.

Skal begrebet om den biologiske fader, i modsætning til ham, som har opdraget én, give nogen mening i en nutidig sammenhæng, må det knyttes til de træk hos et menneske, som netop ikke kan udledes af dets arv og miljø, men som har at gøre med det individuelle $\mathrm{i}$ et menneske, som det ikke automatisk er, men først må blive. I den forstand er det ikke præsidenten, men tværtimod Filip Rose, som måtte udstyres med egenskaben: biologisk fader. I sin egenskab af gammel kulturradikal og inkarneret oprører er Filip Rose det forbillede, som gang på gang kommer skjult til udtryk i Filius' egne handlinger. Men opgøret mellem Filip og Filius kommer aldrig til udfoldelse, fordi deres indbyrdes relation er forvirret af, at Filip er Filius' reelle far i enhver nutidig betydning af ordet: den som han har kendt siden sin f $\varnothing \mathrm{dsel}$, som har opdraget ham og som er parat til at skippe alle sine principper for at skaffe indpas i verden til den dreng, han elsker som en far elsker sin s $\varnothing n$, og aldeles ikke som en stedfader, der har overtaget $\sin$ arvefjendes yngel med henblik på at tilintetgøre dets udspring.

Således drukner den oprindelige, perspektivrige intrige: to fædre, der vil slå hinanden ihjel ved hjælp af den samme søn, i vilkårlighed, forvirring, ordspil og øllebrødsbarmhjertighed. Eller altså: $i$ en uovervindelig schizzofreni, som projiceres ud $i$ et helt samfund.

At slå den far ihjel, som man kender, er i virkeligheden ingen sag. Det lykkes endog for Hamlet. I årene efter 1968 udviklede 
det sig da også til de rene lystmord. Den slags drab finder nemlig altid sted i en højere faderligheds navn: det var de store oprørere, Marx og Freud, der ligitimerede blodbadet, uden at nogen bemærkede, hvilke skrækindjagende overjeg'er der i broderskabets og bevidstgørelsens forklædninger rykkede ind overalt, hvor de gamle forfaldt. Herom vidner bedre end noget andet de spændende og perspektivrige Livsstykker, som fem fhv. ungdomsoprørere for nylig har udgivet. Men det er en anden og meget længere historie.

\section{PARADIGMET}

\section{Det ukendte trae}

På baggrund af den foregående fremstilling er det nærliggende at stille, hvis ikke sig selv, så i hvert fald mig det spørgsmål, hvordan det kan gå til, at én og samme person skriver to bøger, hvoraf den ene kan tilskrives en erkendelses- og underholdningsværdi, som i alt væsentligt frakendes den anden. Jeg tror ikke, at spørgsmålet kan besvares uafhængigt af emnerne.

En del af forklaringen ligger jo uden tvivl i, at Carlsberg-bogen efter alt at d $ø$ mme er skrevet på et overskud, i en lakune under det hårde slid med Villy Sørensens fortællinger. Den er lavet til lejligheden, nemlig Carlsbergfondets 100 -års jubilæum, og hviler på en lykkelig blanding af en i forvejen akkumuleret viden og et næsten uopdyrket stof.

Men det egentlige svar tror jeg skal findes i en indbygget modsigelse i Villy Sørensens forfatterskab, som Bonde Jensen har $\emptyset$ nsket at ophæve. Det har at gøre med Bonde Jensens grundlæggende hensigt med Litterar arkaologi: via beskæftigelsen med Formynderfortallinger at forene modsætningerne ikke blot mellem intern og ekstern kritik, men også mellem de to sider af Villy Sørensens forfatterskab, som efter min mening er uforenelige: hans fantastiske fortællinger og hans moral-filosofiske produktion.

Det var jo ikke noget tilfælde, at kritikken af Bonde Jensens opfattelse af En fremtidshistorie samtidig kom til at forme sig som en kritik af historien selv. Kritikken gik ikke ud på, at $E n$ 
fremtidshistorie skulle være en i almindelig forstand dårlig historie. Personligt synes jeg, det er den bedste af Formynderfortallingerne og har hvergang læst den med lige stor fornøjelse. Den har det tilfælles med mange andre af Villy Sørensens fortællinger, at den benytter et mytisk mønster til at trække grundlaget væk under samtlige implicerede personer, incl. Bonde Jensen. Det var ikke derom kritikken drejede sig, men om at det mytiske mønster selv har trukket grunden væk under sin forfatter, så at han er kommet til at sige noget, han ikke havde tænkt sig, eller altså: noget som ikke er tænkt til ende.

For tolv år siden skrev jeg en lille afhandling om dette særlige, grundlæggende træk ved Villy Sørensens historier: at de udfoldede sig efter en lovmæssighed, som på sin vis suspenderede Villy Sørensen selv, eller rettere: halvdelen af ham. At de havde karakter af et autonomt kompleks, der med sit særlige ironisknihilistiske anlægspræg stod i skarp kontrast til den moralske, opbyggelige tendens, som prægede hans filosofiske forfatterskab. ${ }^{15}$

Det er en opfattelse, jeg gerne vil udbygge lidt. Dels fordi jeg stadig synes den står ved magt, dels fordi jeg ikke mere synes, den gør det. Den passer på udviklingen i hans forfatterskab frem til og med Formynderfortallinger, men den passer ikke på en del af det forfatterskab, som er kommet til udfoldelse siden. Nu som dengang vil jeg til at eksemplificere min opfattelse benytte den fortælling, som jeg regner for forfatterskabets ur-beretning eller paradigme: Det ukendte tra.

Det regner Bonde Jensen den på sin vis også for. Den kunne efter hans mening godt have stået som optakt til hele forfatterskabet. Han anser den for en foregribelse af forsoningen mellem drift og ånd. Hvordan han når frem til det resultat, forstår jeg ikke. Hans egen udlægning drejer sig, så vidt jeg kan se, kun om driften. Han udnævner det ukendte træ til en fallos og dets blomsterkrone til en sæd-udtømning. Sønnens næse er et fallossymbol og det er de snabelsko, han kravler op i træet med, også. Når drengen er utilfreds med ikke at kunne komme til at »spille bold « $i$ haven, er det fordi han shverken kan komme til at lege eller bolde«, understreger Bonde Jensen, som også fastslår, at når 
drengen falder ned og brækker sin hals om efteråret, er det et andet udtryk for »kastration eller radbrækning af lemmet (halsen)« (204-05).

Det er for mig ikke muligt at se Bonde Jensens formål med at læse historien så piccolo-uniformt. Selv retter han ved en anden lejlighed den indvending mod visse af Villy Sørensens historier, at den billedlige fremstilling ikke er autentisk, men »i for h $\varnothing j$ grad blot billede på noget andet, som foreligger som et bevidsthedsfaktum f $\varnothing \mathrm{r}$ billedet « (229). Det må i hvert fald gælde for Bonde Jensens eget vedkommende, når han remplacerer en fortællings mangfoldige detaljer med et fuldstændig monotont genkommende bevidsthedsfaktum. At udlægge en fortælling som $D e t$ ukendte tra kan ikke bestå $\mathrm{i}$ at slå op $\mathrm{i}$ et katalog over seksualsymboler, men at beskrive de funktionssammenhænge, hvori fortællingens personer og konkrete miljø indgår.

\section{Et eksempel: Gartneren og hans søn}

Ligesom En fremtidshistorie handler også Det ukendte tra om en generationskonflikt. Faderen er kgl. hofgartner og et ualmindeligt vellykket eksemplar af slagsen. Fortællingen $\mathrm{g} \phi \mathrm{r}$ ganske vist nar ad hans store indsigt, men dokumenterer dog via sin beskrivelse af hans botaniske have, at den ikke alene er stor, men også beror på en lykkelig, gengældt kærlighed til tingene omkring ham. Han elsker sine blomster og sin $s \emptyset n$, som er udstyret med fremragende anlæg for at efterfølge ham i hans embede.

Men i haven står der altså dette ukendte træ, fra hvis blomstrende krone der udgår et helt vidunderligt skær, som næsten fordunkler solen. Imellem dette træ og hele den $\phi v$ rige have er der en klar modsætning, som den følgende historie uddyber til en fuldstændig skizzofreni. For da sønnen først, vejledt af sin fine lugtesans, er klatret op i træet, hverken vil eller kan han komme ned igen, undtagen altså ved at $\mathrm{d} \phi$ og genopstå $\mathrm{i}$ et nyt træ. Ikke alene fikseres såvel hans som faderens bevidsthed totalt omkring hans nye placering, men træet truer også med langsomt at suge alt liv ud af såvel havens $\emptyset$ vrige vækster som af faderen selv.

Men hvad der for den gamle gartner er hans livs tragedie og 
skam, er for alle andre en sensation, en succes og en seværdighed. Hele fortællingen igennem kommer folk strømmende til i hobetal for at beundre disse fantastiske gevækster, om hvis tilblivelsesbetingelser de ikke aner det ringeste. Den stadig mere fortvivlede kamp mellem faderen og s $\varnothing$ nnen forbliver en hemmelighed imellem de to, som ender med at faderen, efter to gange forgaves at have fors $\emptyset \mathrm{gt}$ at hente sønnen ned eller få ham knækket, selv er en knækket mand; historiens tredie og sidste træ udfolder sig hinsides enhver normalbevidsthed: er opstået af graven og blomstrer et sted oppe $i$ den syvende himmel, mens den døende fader selv futter omkring ved træets fod med vandkanden: »Hør han synger endnu, sagde han til alle de mennesker der kom forbi, og de nikkede, mens de så skråt ned i jorden og holdt læberne tæt mod hinanden «. ${ }^{17}$

Sådan forstået handler fortællingen ikke så meget om et forhold mellem to mennesker, som om et forhold imellem to bevidsthedsfunktioner indenfor det samme menneske. I historiens slutsituation har der fundet en total adskillelse sted imellem på den ene side en grundigt isoleret, modernistisk frigjort fantasiudfoldelse, på den anden en helt udtæret, afmægtigt tjenende intellektualitet. Men fantasi og intellekt fremstår ikke som alment eksisterende evner. De er slutprodukter af en udviklingsgang, som fra begyndelsen rummer et mægtigt, differentieret potentiel. Ligesom det ukendte træ kan opfattes som den rene essens af den mangfoldighed af blomster, som faderen har opdyrket $i$ sin have, sådan er også faderens viden og indsigt forvandlet og koncentreret til ubevidst, medfødt talent i sønnens vibrerende lugtesans. Historiens spænding og tragik kommer af, at bevidst indsigt og ubevidst evne, voksen og barn, er uden sans for hinanden og blindt forlænger deres egen foreløbige eksistens ud i evigheden eller altså: intetheden.

I den forstand fungerer Det ukendte tra som en slags fingeraftryk af Villy Sørensens totale produktion frem til og med Formynderfortallinger, og den kan efter min mening udlægges på samme måde, som Josef nede i Faraos fangehul udlægger sine medfangers drømme: som en forudbestemmelse af gangen i Villy Sørensens forfatterskab. 
I al profetisk korthed: de tre træer er de tre fantastiske fortælling-samlinger, Sare historier, Ufarlige historier og Formynderfortallinger. Det første fors $\emptyset \mathrm{g}$ på at hente sønnen ned er Digtere og damoner. Det andet fors $\emptyset \mathrm{g}$ er Hverken-eller, og skizzofrenien fuldbyrdes i Formynderfortallingers tilsyneladende forsoning af modsætningerne. Mens Digtere og damoner kan ses som et fors $\emptyset \mathrm{g}$ på at få frugtbargjort den kunstnermyte, som lever sit hensynsløse, nihilistisk selvophævende liv i Sare historier, så er Hverken-eller en måde at forsone de samfundsmodsætninger på, som så ironisk kværner hinanden ned i Ufarlige historier. I Formynderfortallinger er filosofien omsider blevet fantasiens tjener. Bogen igennem vader faderen rundt og vander det ukendte træ, som også dufter bedøvende $\mathrm{i}$ den anden og den næstsidste af samlingens fortællinger. Her registreres de særeste, mest fantastiske og helt utrolige ting af et fuldstændig passivt, goldt og afmægtigt intellekt: drøm og tydning synes ikke længere at have noget med hinanden at bestille. Og det er svært ikke at se skråt ned $\mathrm{i}$ jorden og holde læberne tæt mod hinanden, når Bonde Jensen i den gamle gartners sted forsikrer, at han netop $i$ de to fortællinger kan registrere helt suveræne, højt bevidste former for kunstudfoldelse.

\section{Villy Sфrensen}

Men slutningen på Det ukendte trae er jo ikke slutningen på Villy Sørensens forfatterskab. Der har i den senere del af hans produktion fundet en karakteristisk forskydning sted, der nok kommer tydeligst til udtryk i bogen om Seneca, som i sin skildring af forholdet mellem filosoffen og kejseren $i$ en vis forstand gentager generationskonflikten mellem gartneren og hans søn. Men med den forskel, at mens Det ukendte trae er fortalt på en sådan måde, at læserens sympati uvilkårligt placeres hos sønnen, så er sammenhængen og sympatien i Seneca på den fædrene side. Her som dér ender det med at faderen må bukke under for sønnen, men i sin død besejrer Seneca netop Nero og er for længst kommet hinsides den konflikt, som kejseren livslangt fikseres af.

Seneca kan da også godt opfattes som det første egentlige eks- 
empel i Villy Sørensens forfatterskab på den forsoning mellem fantasi og intellekt, som blev antydet $i$ forbindelse med Bonde Jensens Carlsberg-bog. Som Bonde Jensen gør det i generationskonflikten mellem den gamle og den unge brygger Jacobsen, sådan søger også Villy Sørensen i sin skildring af lærer-elev forbindelsen mellem Seneca og Nero at sammenfatte og stilisere hele den antikke samfundsudvikling og at fremstille Seneca som et paradigme, der tillige omfatter fremtiden. Om dette fors $\emptyset \mathrm{g}$ kan man have forskellige meninger, og for mit eget vedkommende er jeg temmelig uenig med det meste af, hvad Villy Sørensen skriver om antikken. Men det hverken kan eller skal forhindre mig $\mathrm{i}$ at sympatisere med bogen som helhed. Læst som oplæg til Oprør fra midten rummer den spændende perspektiver.

Fors $\phi$ ger man at sammenligne Villy Sørensens position med andre forfatteres af samme ry og format, kan man jo godt føle sig slået af den særlige modsætning mellem offentlig og privat person, som gør sig galdende for hans vedkommende. Han har ikke som en Blixen, en Rifbjerg eller en Reich arbejdet på at gøre sit eget liv til en offentlig myte. Alle kender de sære historier og de moralske tanker, også selvom de ikke har læst nogen af dem, men manden i midten smiler sfinksagtig til læseren på billederne over forlagsannoncerne for hans værker.

Det kunne se ud til, at Villy Sørensens myte skal være den: ingen myte at have. Det stemmer på sin vis også meget godt overens med pointerne $i$ de tre fortælling-samlingers tre centrale udviklingshistorier: Tigrene, Kфbmanden og En fremtidshistorie, som foruden hovedpersonemes genert-oprigtige gemyt også er fælles om at spille på navneligheden ikke alene mellem Fif, Filip og Filius, men også på den udtale af sit fornavn, som Villy Sørensen mødte under sin ungdoms studieophold i Tyskland: Fili. ${ }^{18}$

I alle tre historier hersker der helt uløselige forviklinger mellem det at ofre sig og det at svigte. Alle tre handler de om en udvalgt, der er født ind i familie- og samfundsforhold, som er ude af stand til at forstå, endsige løse såvel hovedpersonens som deres egne problemer. Alle tre handler de om, hvordan den udvalgte bliver en udstødt: en isoleret, forfulgt og diskrimineret 
person, der i udstødelsen ofrer sig selv som privatmand og dermed også ofrer de menneskelige relationer, hvori han indgår, for siden at vende tilbage som forløser for de mennesker og forbundet med den midte, hvoraf han lod sig udstøde.

Hvor meget eller hvor lidt det nu har på sig, så er det jo i hvert fald givet, hvis man går ud fra de læserundersøgelser, hvormed Bonde Jensen begynder sin bog, at den mand, som efter enhver sociologisk og litteratursociologisk målestok burde anbringes i yderkanten af den finkulturelle yderkant, siden Bonde Jensen skrev sin bog har anbragt sig i midten af den hjemlige offentlighed. Man kan være enig eller uenig med Villy Sørensen, men han står $\mathrm{i}$ dag indiskutabelt som den helt centrale skikkelse og foregangsmand for det kommende årtis samfundsdebat. Vejen frem går igennem ham. Det er ikke til at komme udenom. 


\section{NOTER}

Sidehenvisningerne i parentes inde i teksten henviser til følgende udgaver: Jørgen Bonde Jensen: Litterar arkaologi. Studier $i$ Villy Sфrensens Formynderfortallinger. København 1978.

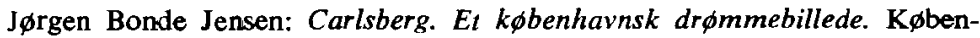
havn 1976.

Villy Sørensen: Formynderfortallinger. København 1964, (FF).

1 Jørgen Bonde Jensen: >Om Villy Sørensen: En glashistorie«, i Analyser af dansk kortprosa, red. af Jørgen Dines Johansen, 1972, Bd. II s. 165-84.

2 Ebbe Sфnderriis: Villy Sфrensen. En ideologikritisk analyse. Århus 1972 , s. 132.

3 Claus Clausen: Digtere i forh $\phi r$. København 1966, s. 30.

4 Det drejer sig om følgende afhandlinger indenfor samme temakreds som den nærværende: -Tekst og historie. Omkring Ødipus som paradigme i KRITIK 35. Tekst, historie og samfund - i Karen Blixens Sorg-Agre a i KRITIK 41. De forbyttede børn. Tekst, historie og samfund i Karen Blixens En Herregaardshistorie i Blixeniana 1978, red. af Frans Lasson. Samt afhandlingerne om Augustin og Grundtvig i min bog Viljens former. København 1974.

5 Thorkild Bjørnvig: Pagten. København 1974, s. 36.

6 Eksemplerne kan findes på følgende sider $\mathrm{i}$ Bonde Jensens fremstilling: 212, 204 og 91.

7 Formynderfortallinger s. 100: $>0$ felix culpa quae tantum meruit redemptorem *

8 jf. KRITIK 35 , s. 37.

9 Historien $i$ dansk, udg. af Dansklærerforeningen. København 1978, s. 199-208.

10 Ibid. s. 201.

11 Ibid. s. 199.

12 Aage Henriksen: sumaniora i støbeskeen i KRITIK 46, s. 23.

13 Jf. de f $\phi \mathrm{r}$ omtalte afhandlinger i KRITIK 41, s. $102-04$ samt i Blixeniana 1978 , s. 59-68.

14 Vindrosen 1961, III 250.

15 Jf. KRITIK 35, s. 67-68.

16 Poul Behrendt: - Det ukendte træ $\alpha$ i KRITIK 3, s. 3-23.

17 Villy Sørensen: Sare historier. København 1953, s. 91.

18 For også selv at komme med et bidrag til den anagrammatiske galskab vil jeg gerne påstå, at navnet Filip Rose slet ikke, som Bonde Jensen foreslår (140-41), er dannet over tre græske ord og betyder hesteelsker eros, men at Filip Rose og Filius tilsammen spiller på den tyske udtale af Villy Sørensen: Fili Sore(n)søn.

10 Dansk og historie 